\title{
Modelling borehole temperatures in Southern Norway - insights into permafrost dynamics during the 20th and 21 st century
}

\author{
T. Hipp, B. Etzelmüller, H. Farbrot, T. V. Schuler, and S. Westermann \\ Department of Geosciences, University of Oslo, Oslo, Norway \\ Correspondence to: T. Hipp (tobias.hipp@geo.uio.no) \\ Received: 30 December 2011 - Published in The Cryosphere Discuss.: 27 January 2012 \\ Revised: 20 April 2012 - Accepted: 28 April 2012 - Published: 23 May 2012
}

\begin{abstract}
This study aims at quantifying the thermal response of mountain permafrost in southern Norway to changes in climate since 1860 and until 2100. A transient one-dimensional heat flow model was used to simulate ground temperatures and associated active layer thicknesses for nine borehole locations, which are located at different elevations and in substrates with different thermal properties. The model was forced by reconstructed air temperatures starting from 1860, which approximately coincides with the end of the Little Ice Age in the region. The impact of climate warming on mountain permafrost to 2100 is assessed by using downscaled air temperatures from a multi-model ensemble for the A1B scenario. Borehole records over three consecutive years of ground temperatures, air temperatures and snow cover data served for model calibration and validation. With an increase of air temperature of $\sim 1.5^{\circ} \mathrm{C}$ over $1860-2010$ and an additional warming of $\sim 2.8^{\circ} \mathrm{C}$ until 2100 , we simulate the evolution of ground temperatures for each borehole location. In 1860 the lower limit of permafrost was estimated to be ca. $200 \mathrm{~m}$ lower than observed today. According to the model, since the approximate end of the Little Ice Age, the active-layer thickness has increased by $0.5-5 \mathrm{~m}$ and $>10 \mathrm{~m}$ for the sites Juvvasshøe and Tron, respectively. The most pronounced increases in active layer thickness were modelled for the last two decades since 1990 with increase rates of $+2 \mathrm{~cm} \mathrm{yr}^{-1}$ to $+87 \mathrm{~cm} \mathrm{yr}^{-1}(20-430 \%)$. According to the A1B climate scenario, degradation of mountain permafrost is suggested to occur throughout the 21 st century at most of the sites below ca. $1800 \mathrm{~m}$ a.s.l. At the highest locations at $1900 \mathrm{~m}$ a.s.l., permafrost degradation is likely to occur with a probability of $55-75 \%$ by 2100 . This implies that mountain permafrost in southern Norway is likely to be confined to the highest peaks in the western part of the country.
\end{abstract}

\section{Background and objectives}

Permafrost in general and mountain permafrost in particular experiences increasing interest due to its sensitivity to climate variation and importance for geomorphologic and geotechnical processes (Harris et al., 2009), such as slope stability and natural hazards (Gude and Barsch, 2005; Huggel et al., 2010; Gruber et al., 2004a; Fischer et al., 2006; Haeberli, 1992). There is a need to address the response of ground temperatures (GT) to climate forcing, especially the modulation of the response of GTs to the effect of snow cover and different types of surficial material and bedrock.

This study aims at the quantification of subsurface warming and changes in active layer thickness (ALT) over a ca. $250 \mathrm{yr}$ period from the approximate end of the Little Ice Age (LIA) in the mid 19th century to 2100 at three highmountain sites in Southern Norway. Significant warming occurred during that period and is expected to continue. In relation to these changes, we intend to identify the possible zonations of former, present and future permafrost. Finally, we aim to characterise these responses for different environmental settings in terms of bedrock properties, sediment-cover and snow. We suggest that these assessments are fundamental prerequisites for spatially distributed permafrost modelling in Scandinavia, and for understanding geomorphological process patterns and ultimately landscape development (Berthling and Etzelmüller, 2011).

One-dimensional heat flow models have been applied in various permafrost studies to assess the response of permafrost to climate change, such as for arctic permafrost (Burn and Zhang, 2009; Etzelmüller et al., 2011; Osterkamp and Romanovsky, 1999; Romanovsky et al., 2007; Sazonova et al., 2004; Zhang et al., 2006, 2008) and mountain permafrost in the European Alps (Engelhardt et al., 2010; 

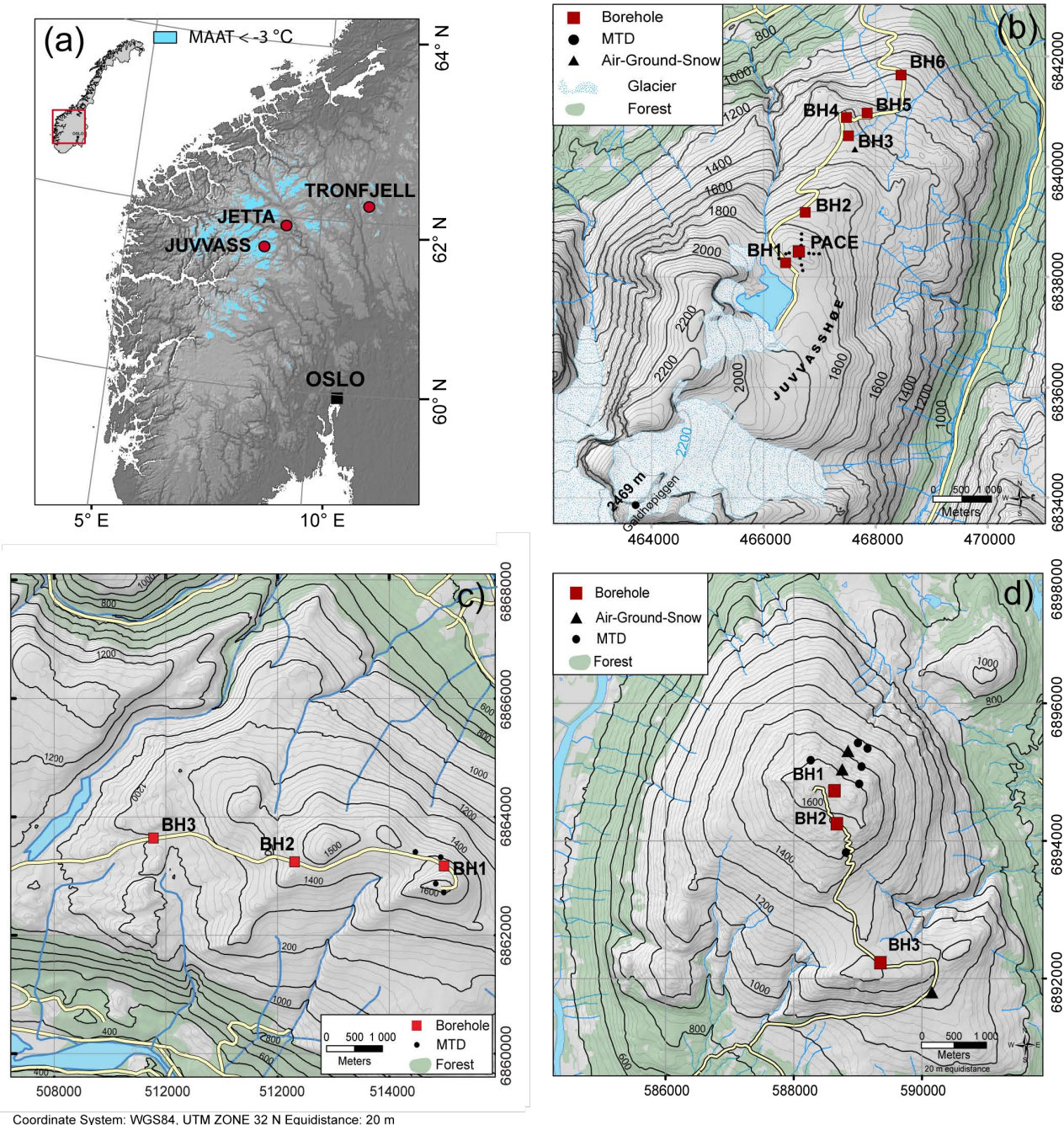

Fig. 1. Location of the study sites and boreholes in Norway (a). As a rough estimate of possible permafrost distribution all areas with MAAT $<-3{ }^{\circ} \mathrm{C}$ during the last normal period 1961-1990 are shown in blue (Etzelmüller et al., 2003). Local site overview of (b) Juvvasshøe, (c) Jetta and (d) Tron, each indicating the locations of boreholes (BH), where GST measurements (MTD) and $T_{\mathrm{AIR}}$, GST and snow depth measurements are performed.

Gruber and Hoelzle, 2008; Gruber et al., 2004b; Hoelzle et al., 2001; Luetschg et al., 2008; Noetzli and Gruber, 2009; Noetzli et al., 2007; Scherler et al., 2010; Stocker-Mittaz et al., 2002).

In this study, we apply a 1-D heat flow model (Etzelmüller et al., 2011; Farbrot et al., 2007) to simulate GTs and ALT for the time period of 1860 until 2100 in the mountains of Southern Norway. In addition to the existing PACE borehole (Isaksen et al., 2001) in 200812 shallow boreholes have been established recording GT, GST and $T_{\mathrm{AIR}}$ at three different mountain areas in Southern Norway. Forcing the calibrated model using reconstructed and projected $T_{\mathrm{AIR}}$ series, we assess how sensitive GT and ALT react to warming at the investigated sites, including an assessment of model limitations and related uncertainties of our approach.

\section{Setting, instrumentation and climate at the study sites}

We use borehole measurements from three locations in Southern Norway in this study (Fig. 1a): Juvvasshøe $\left(61^{\circ} 40^{\prime} \mathrm{N}, 08^{\circ} 22^{\prime} \mathrm{E}, 1894 \mathrm{~m}\right.$ a.s.1.), Jetta $\left(61^{\circ} 53^{\prime} \mathrm{N}, 9^{\circ} 17^{\prime} \mathrm{E}\right.$, $1560 \mathrm{~m}$ a.s.1.) and Tron $\left(62^{\circ} 10^{\prime} \mathrm{N}, 10^{\circ} 41^{\prime} \mathrm{E}, 1640 \mathrm{~m}\right.$ a.s.1.). At these sites, ground temperature records are available at 13 borehole locations covering the period September 2008 to July 2011. At Juvvasshøe, the PACE borehole ground temperature data is available from 1999 (Isaksen et al., 2001, 2007). Data from all boreholes were used in this chapter to give an introduction to the climate and geomorphological settings at the study sites. However, only a selection of nine boreholes (Table 1) was used for the modelling study. 


\subsection{The borehole sites and instrumentation}

At Juvvasshøe (1894 m) (Fig. 1b) first ground temperature measurements started by Ødegård et al. (1992) and the later drilling of the $129 \mathrm{~m}$ deep PACE borehole (Harris et al., 2001; Isaksen et al., 2001). The site is characterised by extensive block fields at higher elevations and finer till material at lower elevations (Ødegård et al., 1988). Six boreholes were drilled in addition to the existing PACE boreholes, resulting in an altitudinal transect from $1894 \mathrm{~m}$ a.s.l. (PACE) down to $1307 \mathrm{~m}$ a.s.l. (Juv-BH6) (Fig. 1b). The boreholes have different stratigraphies: PACE, Juv-BH1 and Juv-BH3 are located in block fields; Juv-BH4 was drilled in bedrock and Juv-BH6 in a sand- to gravel-rich ground moraine.

At Jetta (Fig. 1c) block fields are present down to elevations of $1500 \mathrm{~m}$ and $1100 \mathrm{~m}$ a.s.l. on the north and south exposition, respectively, with thicknesses ranging from 3 to $10 \mathrm{~m}(\mathrm{~B} \emptyset, 1998)$. Three boreholes were drilled $10 \mathrm{~m}$ into bedrock at $1560 \mathrm{~m}$ a.s.l. (Jet-BH1), $1450 \mathrm{~m}$ a.s.l. (Jet-BH2) and $1218 \mathrm{~m}$ a.s.l. (Jet-BH3), respectively.

Tron (Fig. 1d) is located further east in a more continental climate setting. Two boreholes were drilled $10 \mathrm{~m}$ into fine-grained morainic material (Tro-BH1, Tro-BH2), while the uppermost borehole (Tro-BH1, $1640 \mathrm{~m}$ ) was drilled $30 \mathrm{~m}$ into a block field.

At all boreholes, GST, $T_{\mathrm{AIR}}$ and snow depth (SD) are recorded. Following the approach by Lewkowicz (2008) Maxim ${ }^{\odot}$ iButton temperature loggers $\left( \pm 0.5^{\circ} \mathrm{C}\right.$ accuracy $)$ at fixed heights above the ground surface $(10,20,30,40,50$, $60,80,100,120 \mathrm{~cm}$ ) were used to extract SD. At PACE and Tron automatic weather stations record several meteorological variables to characterise the surface energy balance.

\subsection{Climate and ground thermal conditions at the study sites}

The sites are situated along a continentality gradient from a more maritime influenced climate at Juvvasshøe to a more continental climate setting at Tron (Farbrot et al., 2011). The entire observation period from September 2008 to July 2011 was divided into three parts (S1: September 2008 to August 2009; S2: September 2009 to August 2010; S3: September 2010 to July 2011) to analyse the inter-annual variation (Table 1). As S3 does not cover a complete seasonal cycle, it is not used for comparison or $n$-factor calculations.

At Juvvasshøe MAATs during S1 ranged from $-3.4^{\circ} \mathrm{C}$ to $-0.6^{\circ} \mathrm{C}$ and during S2 from $-4.5^{\circ} \mathrm{C}$ to $-2.3{ }^{\circ} \mathrm{C}$ between $1894 \mathrm{~m}$ a.s.l. and $1307 \mathrm{~m}$ a.s.l. At higher elevations snow cover is highly variable and generally thin $(<20 \mathrm{~cm})$ due to strong redistribution by wind (Fig. 2a). A thick snow cover is found at lower elevations $(70-140 \mathrm{~cm})$ (Table 1, Fig. 2b). The lower limit of permafrost along the instrumented slope is at ca. $1450 \mathrm{~m}$ a.s.l. (Farbrot et al., 2011). Permafrost thickness at the PACE borehole was estimated to be approximately $380 \mathrm{~m}$ (Isaksen et al., 2001). During the study period, observed ALT varied between $1.6 \mathrm{~m}$ (Juv-BH1) (Fig. 2a) and $8.6 \mathrm{~m}$ (Juv-BH4). The mean annual ground temperature at $10 \mathrm{~m}$ depth $\left(\mathrm{MAGT}_{10}\right)$ ranges from $-2.5^{\circ} \mathrm{C}$ to $-0.3^{\circ} \mathrm{C}$ within permafrost and reaches up to $+1.7^{\circ} \mathrm{C}$ (Juv-BH6) in non-permafrost areas (Table 1).

At Jetta, MAATs between $-2.2^{\circ} \mathrm{C}$ to $-0.2^{\circ} \mathrm{C}$ were recorded during $\mathrm{S} 1$ and $-3.7{ }^{\circ} \mathrm{C}$ to $-1.6{ }^{\circ} \mathrm{C}$ during S2 between $1560 \mathrm{~m}$ a.s.l. to $1218 \mathrm{~m}$ a.s.l. (Table 1). A long-lasting, thick snow cover $(>140 \mathrm{~cm})$ is recorded at the uppermost borehole (Jet-BH1) (Fig. 2c), while Jet-BH3 had no significant snow cover due to strong wind drift (Fig. 2d). Therefore, despite the lower elevation, the GST recorded at Jet$\mathrm{BH} 3$ is even lower than at Jet-BH1 during $\mathrm{S} 2$. The MAGT 10 increases from $-0.8^{\circ} \mathrm{C}$ at Jet-BH1 to ca. $1.7^{\circ} \mathrm{C}$ at Jet-BH3 during the observation period (Table 1). An ALT of ca. 6.9 to $9 \mathrm{~m}$ was recorded at Jet-BH1 (Table 3, Fig. 2c) while seasonal frost penetrates down to 6 to $9 \mathrm{~m}$ depth at Jet-BH3 (Fig. 2d).

At Tron, MAAT during $\mathrm{S} 1$ ranged from $3.6^{\circ} \mathrm{C}$ to $-0.9^{\circ} \mathrm{C}$ and during $\mathrm{S} 2$ from $-4.5^{\circ} \mathrm{C}$ to $-2.3{ }^{\circ} \mathrm{C}$ between $1640 \mathrm{~m}$ a.s.1. to $1589 \mathrm{~m}$ a.s.l. (Table 1). Tro-BH1 and TroBH2 show thick and long-lasting snow cover during both seasons $(>90 \mathrm{~cm}$ ) (Fig. 2e, f). Permafrost was found at the uppermost borehole with GTs only slightly below $0{ }^{\circ} \mathrm{C}$ down to a depth of $30 \mathrm{~m}$ (Fig. 2e). Despite lower MAAT and MAGST in S2, the ALT at Tron-BH1 slightly increased from $10.7 \mathrm{~m}$ to $11.1 \mathrm{~m}$ (Fig. 2e). Along the north slope of Tron, comparatively low MAGST of $-0.4^{\circ} \mathrm{C}$ to $-0.7^{\circ} \mathrm{C}$ were recorded by miniature temperature loggers down to $1450 \mathrm{~m}$ a.s.l., indicating the possible presence of permafrost (Farbrot et al., 2011). Seasonal frost dominates at the lower borehole (Tro-BH2) with freezing depths of ca. $1.5 \mathrm{~m}$ to $4 \mathrm{~m}$ (Fig. 2f). Similarly an increase of freezing depths was observed during S2 and S3 (Fig. 2f).

\subsection{Seasonal variations}

The air temperature records for different sites and seasons display the influence of continentality as well as strong inter-annual variations. To better analyse these differences, we calculated anomalies of mean monthly air temperatures (MMAT) for all three sites for 2008-2011 with respect to the climate normal 1961-1990 (Fig. 3). Despite the lower elevation of Tronfjell, $T_{\mathrm{AIR}}$ is similar or lower than at Juvvasshøe and Jetta (Fig. 3a). Using altitudinal lapse rates derived from observations (Farbrot et al., 2011), MAAT at $1640 \mathrm{~m}$ a.s.1. is $-2.3,-2.2$ and $-3.8^{\circ} \mathrm{C}$ at Juvvasshøe, Jetta and Tron, respectively. The MAAT of S1 was by $1.0^{\circ} \mathrm{C}$ to $1.7^{\circ} \mathrm{C}$ higher than the last normal period $1961-1990$. The MAAT of S2, however, was $-0.5^{\circ} \mathrm{C}$ lower at Juvvasshøe and $0.3^{\circ} \mathrm{C}$ to $0.4^{\circ} \mathrm{C}$ higher at the other sites. The largest deviation to the normal is found during winter of $\mathrm{S} 2$ where temperatures during December to February are up to $4.5^{\circ} \mathrm{C}$ lower than normal (Fig. 3b). In general, S2 was on average $1.4^{\circ} \mathrm{C}$ to $1.1^{\circ} \mathrm{C}$ colder than $\mathrm{S} 1$. 

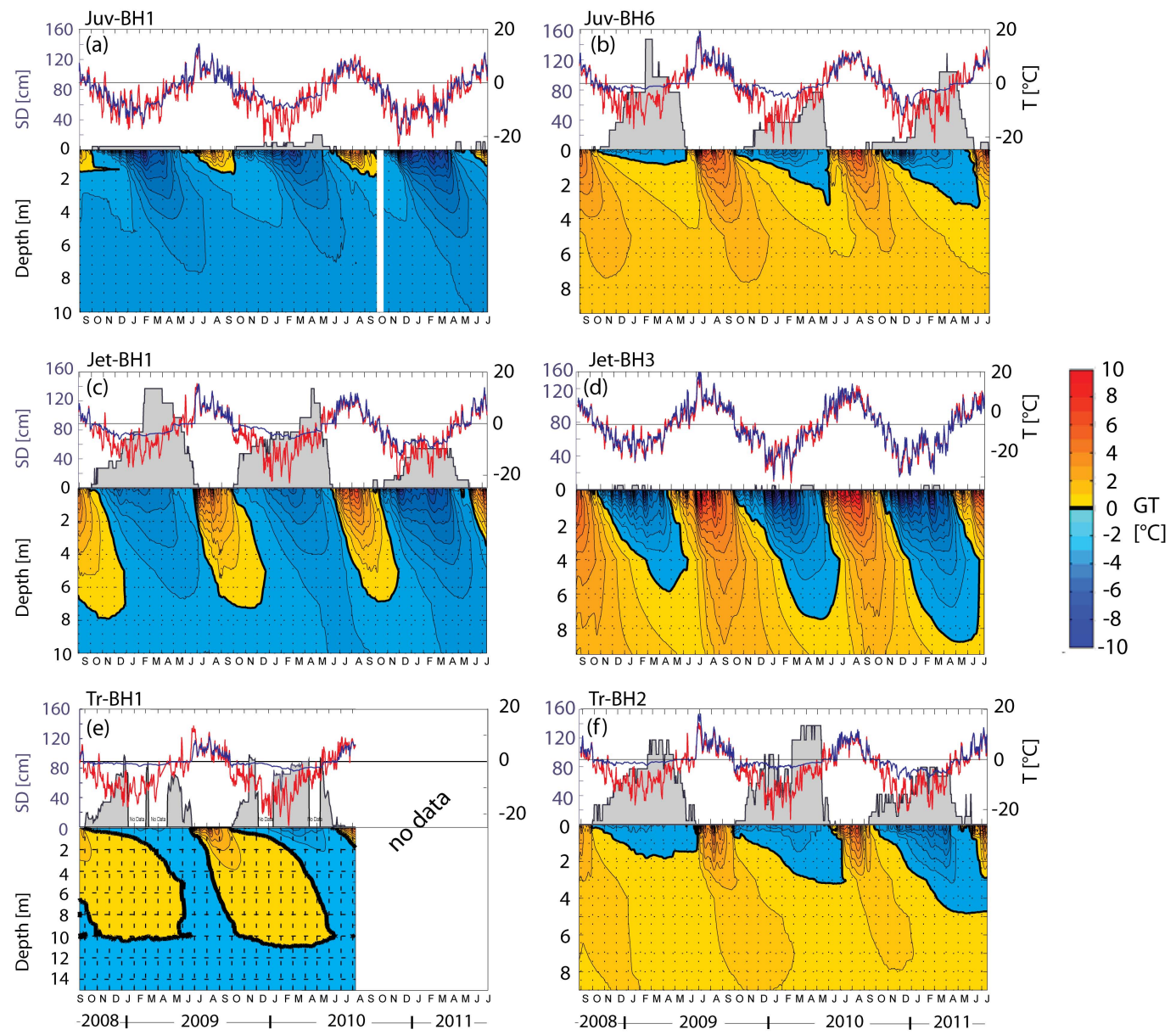

Fig. 2. Thermal regime of permafrost and non-permafrost borehole sites at Juvvasshøe (a, b), Jetta (c, d) and Tron (e, f) comprising GT, GST, $T_{\text {AIR }}$ and snow depth (SD). The upper panel in each figure shows $T_{\text {AIR }}$ (red line), GST (blue line) and SD (grey area). The lower panel in each figure represents a depth-time diagram of GT.

The borehole temperatures show different susceptibilities to inter-annual variability depending on the strength of coupling between GST and $T_{\mathrm{AIR}}$ (Fig. 4). Boreholes having a close atmosphere-ground coupling show much lower GSTs and GTs in S2. The GSTs of S2 at Juv-BH3 and the bedrock site Juv-BH4 were by $0.6^{\circ} \mathrm{C}$ and $2.1{ }^{\circ} \mathrm{C}$ lower, respectively, than during S1 (Table 1). While Jet-BH1 shows a rather constant MAGST during both seasons due to extensive snow cover (Table 1), strong variations at Jet-BH3 with $+0.5^{\circ} \mathrm{C}$ during $\mathrm{S} 1$ and $-1.0^{\circ} \mathrm{C}$ during S2 (Table 1) demonstrate closer coupling between atmosphere and ground surface (Fig. 4).

\section{Methods}

\subsection{1-D numerical heat flow model}

For this study, we used a one-dimensional transient heat flow model, which was previously applied in similar stud- ies (Farbrot et al., 2007; Etzelmüller et al., 2011). Assuming heat conduction as the only process of energy transfer the model is solving the heat conduction equation (Williams and Smith, 1989)

$\rho c_{\mathrm{eff}} \frac{\partial T}{\partial t}=\frac{\partial}{\partial z}\left(k \frac{\partial T}{\partial z}\right)$

describing the evolution of the ground temperature $T$ over time $t$ and depth $z$, where specific heat capacity $c_{\text {eff }}(\mathrm{J}$ $\left.\mathrm{kg}^{-1} \mathrm{~K}^{-1}\right)$, thermal conductivity $k\left(W \mathrm{~K}^{-1} \mathrm{~m}^{-1}\right)$ and density $\rho\left(\mathrm{kg} \mathrm{m}^{-3}\right)$ are the main thermo-physical properties of the ground. All borehole stratigraphies were implemented in the model at a spatial resolution of $\Delta z=0.1 \mathrm{~m}$ by assigning ground thermal properties according to the observed stratigraphy (Table 2). The heat conduction Eq. (1) is then solved using finite differences along the borehole profile to a depth of $150 \mathrm{~m}$. The volumetric water content (VWC) is considered in the model as a constant. The effect of latent heat due to freezing and thawing of the ground is accounted 
Table 1. Thermal conditions at individual boreholes included in the modelling study, showing mean annual air temperature (MAAT), mean annual ground surface temperature (MAGST) and ground temperature at $10 \mathrm{~m}$ depth $\left(\mathrm{MGT}_{10}\right) . \mathrm{N}_{F^{-}}$and $\mathrm{n}_{T}$-factors for the two seasons 2008/2009 (S1) and 2009/2010 (S2) and the average (AVG) used in the modelling are shown. For 2010/2011 (S3) only $\mathrm{n}_{F}$-factors could be calculated due to missing data for the summer months.

\begin{tabular}{|c|c|c|c|c|c|c|c|c|c|c|c|c|c|c|}
\hline \multirow[t]{2}{*}{ Borehole } & \multirow[t]{2}{*}{ Elevation [m a.s.1.] } & \multicolumn{2}{|c|}{ MAAT } & \multicolumn{2}{|c|}{ MAGST } & \multicolumn{2}{|c|}{$\mathrm{MGT}_{10}$} & \multicolumn{4}{|c|}{$\mathrm{n}_{F}$} & \multicolumn{3}{|c|}{$\mathrm{n}_{T}$} \\
\hline & & $\mathrm{S} 1$ & S2 & S1 & S2 & S1 & S2 & S1 & S2 & $\mathrm{S} 3$ & AVG & S1 & S2 & AVG \\
\hline \multicolumn{15}{|c|}{ JUVVASSHØE } \\
\hline PACE & 1894 & -3.4 & -4.6 & -2.8 & -2.9 & -2.5 & - & 0.93 & - & - & $0.90^{2}$ & 1.17 & - & $1.10^{2}$ \\
\hline BH1 & 1851 & -3.3 & -4.7 & -2.4 & -2.6 & -1.6 & -1.7 & 0.88 & 0.64 & 0.85 & 0.76 & 1.18 & 0.99 & 1.09 \\
\hline $\mathrm{BH} 3$ & 1561 & -1.7 & -3.1 & -0.6 & -1.2 & -0.3 & -0.5 & 0.96 & 0.73 & 0.86 & 0.85 & 1.52 & 1.32 & 1.42 \\
\hline $\mathrm{BH} 4$ & 1559 & -1.7 & -3.1 & -1.1 & -2.6 & - & -0.7 & 1.03 & 1.00 & 0.99 & 1.02 & 1.38 & 1.24 & 1.31 \\
\hline BH6 & 1307 & -0.6 & -2.2 & 1.9 & 0.8 & 1.7 & 1.5 & 0.23 & 0.34 & 0.38 & 0.29 & 1.01 & 0.96 & 0.99 \\
\hline \multicolumn{15}{|l|}{ JETTA } \\
\hline BH1 & 1560 & -2.2 & -3.7 & -0.4 & -0.2 & -0.8 & -0.8 & - & 0.37 & 0.69 & $0.37^{2}$ & - & 0.98 & $1.08^{2}$ \\
\hline $\mathrm{BH} 3$ & 1218 & -0.2 & -1.6 & 0.5 & -1.0 & $1.7_{1}$ & $1.6_{1}$ & 0.96 & 0.99 & 0.96 & 0.98 & 1.22 & 1.21 & 1.22 \\
\hline \multicolumn{15}{|l|}{ TRON } \\
\hline BH1 & 1640 & -3.6 & -4.5 & 0.8 & -0.2 & 0.0 & 0.0 & 0.14 & 0.28 & - & 0.21 & 1.12 & 1.04 & 1.08 \\
\hline $\mathrm{BH} 2$ & 1589 & -3.0 & -3.9 & 1.1 & 0.3 & 0.9 & 0.8 & 0.16 & 0.26 & 0.40 & 0.21 & 1.19 & 1.07 & 1.13 \\
\hline
\end{tabular}

$19.5 \mathrm{~m}$ depth

${ }^{2}$ Estimated during calibration process due to missing data

Table 2. Ground properties for different substrates, surface cover and bedrock type, used in the model. Variations within these generalised surface and subsurface classes at different sites can still be found, thus, the ranges of parameter values are given. Here, $k$ is thermal conductivity, $c$ is specific heat capacity, VWC is the volumetric water content and $\rho$ is the density.

\begin{tabular}{lllll}
\hline & $\mathrm{k}\left[\mathrm{W} \mathrm{K}^{-1} \mathrm{~m}^{-1}\right]$ & $\mathrm{c}\left[\mathrm{J} \mathrm{kg}^{-1} \mathrm{~K}^{-1}\right]$ & $\mathrm{VWC}[\%]$ & $\rho\left[\mathrm{kg} \mathrm{m}^{-3}\right]$ \\
\hline Block field & $0.8-1.4$ & 800 & $5-20$ & $1200-1600$ \\
Vegetated surface layer & 0.8 & 800 & $14-15$ & $1000-1300$ \\
Coarse grained material & $1.8-2.3$ & 800 & 4 & $1400-2000$ \\
Fine moraine material & $1.0-1.8$ & 800 & $4-8$ & $1500-1800$ \\
Bedrock & 2.7 & 900 & 1 & 2600 \\
\hline
\end{tabular}

for by using a temperature-dependent effective heat capacity $c_{\text {eff }}$, which is strongly increased in a temperature interval of $\pm 0.1^{\circ} \mathrm{C}$ around the freezing temperature of the pore water (Etzelmüller et al., 2011). Any effects related to the advection of heat due to flow of ground water or of air in coarse-grained block fields are not considered in the model formulation.

\subsection{Historic and future temperature data}

Surface air temperature series are needed for forcing the heat flow model for historic or future time periods. For the historic period dating back to 1860 , we used data series provided by the Norwegian Meteorological Institute (met.no). HanssenBauer (2005) and Hanssen-Bauer and Nordli (1998) identified six temperature regions for Norway, each of which characterised by similar long-term variability of air temperature, by analysing available long-term temperature records (starting in the 1860s). For each region monthly standardised temperature series $\mathrm{ST}_{m}$ are derived by averaging the standardised temperature series $\mathrm{ST}_{m, i}$ of each individual station $i$ in the region $m$ :

$S T_{m}=(1 / n) \times \sum_{i=1}^{n} S T_{m, i}$

The individual standardised series are presented as anomalies in terms of standard deviations relative to the 1961-1990 average (Hanssen-Bauer, 2005):

$S T_{m, i}=\left(T_{m, i}-\mu_{T m, i}\right) / \sigma_{T m, i}$

where $T_{m, i}$ is the observed temperature series at station $i$ in region $m, \mu T_{m, i}$ the standard normal and for the entire mainland Norway mean daily air temperatures (MDAT) are available as 1-km-resolution maps $\left(\mathrm{MDAT}_{\text {grid }}\right)$ for the period 1 September 1957 until present (provided by the Norwegian Meteorological Institute (met.no), available at http: //senorge.no, from hereon referred to as seNorge dataset). These grids are interpolated (kriging) from recorded temperatures at synoptic weather stations (Mohr, 2009). Daily 
Table 3. Model performance in terms of ground surface temperature (GST), ground temperature (GT) and active layer thickness (ALT) at boreholes included in the modelling study. Model performance for GST and GT is expressed in terms of Nash-Sutcliffe model efficiency. Modelled and observed ALT is presented in absolute values. For GT, both the calibration (C) and the validation (V) periods are listed. For the GST the model was run with the averaged $n$-factors and ME calculated for each season individually.

\begin{tabular}{llllllll}
\hline & \multicolumn{3}{c}{ GST } & \multicolumn{2}{c}{ GT } & ALT $_{\text {meas }}$ [m] & ALT \\
& S1 & S2 & S3 & C & V & S1/S2/S3 & S1/S2/S3 \\
\hline JUVVASSHØE & & & & & & & \\
\hline PACE & 0.89 & 0.85 & - & 0.88 & 0.84 & $2.2 / 2.3 /-$ & $2.1 / 2.1 /-$ \\
BH1 & 0.89 & 0.86 & 0.89 & 0.84 & 0.82 & $1.4 / 1.5 / 1.6$ & $1.4 / 1.3 / 1.2$ \\
BH3 & 0.88 & 0.86 & 0.92 & 0.90 & 0.89 & $8.5 / 6.8 / 5.6$ & $8.2 / 6.4 / 5.4$ \\
BH4 & - & 0.92 & 0.96 & $0.99^{*}$ & $0.93^{*}$ & $-/ 8.6 / 6.6$ & $-/ 8.4 / 6.7$ \\
BH6 & 0.91 & 0.88 & 0.89 & 0.92 & 0.90 & - & - \\
\hline JETTA & & & & & & & $8.1 / 7.9 / 6.7$ \\
\hline BH1 & 0.87 & 0.85 & 0.80 & 0.91 & 0.90 & $8.0 / 7.3 / 6.9$ & - \\
BH3 & 0.96 & 0.95 & 0.91 & 0.95 & 0.93 & - & $11.7 / 10.7 /-$ \\
\hline TRON & & & & & & & - \\
\hline BH1 & 0.71 & 0.81 & - & 0.92 & 0.89 & $10.7 / 11.1 /-$ & \\
BH2 & 0.90 & 0.92 & 0.80 & 0.85 & 0.82 & - & \\
\hline
\end{tabular}

*Calibration: S2; Validation: S3

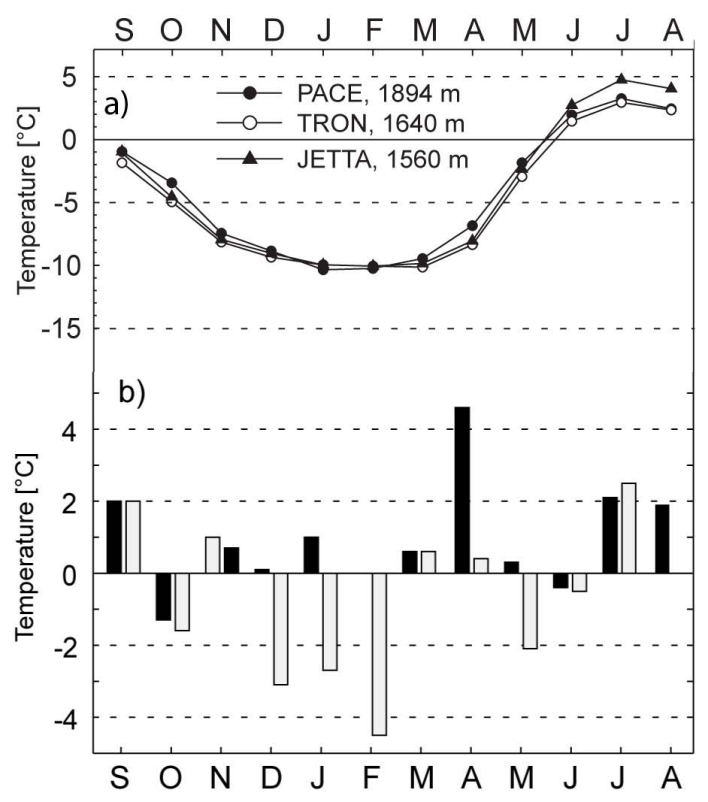

Fig. 3. (a) Mean monthly air temperatures for the PACE borehole at Juvvasshøe, Tron-BH1 and Jet-BH1 during the last normal period 1961-1990. (b) Monthly air temperature deviations from the normal 1961-1990 at the PACE borehole for S1 (black) and S2 (grey).

air temperatures from 1957 to 2008 were generated for the boreholes PACE, Jet-BH1 and Tro-BH1 using linear regressions between measured temperatures during 2008 to 2011 and those extracted from seNorge for the corresponding lo- cation. This procedure worked well for PACE with $r^{2}=0.8$ and a RMSE of $3.1^{\circ} \mathrm{C}$. For Jet-LB1 and Tro-BH1, however, the relation between observed air temperature and the corresponding seNorge value is nonlinear, displaying a sharp bend at low temperatures. This characteristic is associated with the frequent occurrence of temperature inversions during winter (Farbrot et al., 2011), which are not captured by the seNorge dataset. To cope with this problem, two separate linear regressions were performed for each site, one above and one below a threshold temperature $\left(-10^{\circ} \mathrm{C}\right.$ and $-5^{\circ} \mathrm{C}$ for TroBH1 and Jet-BH1, respectively).

For the normal period 1961-1990 mean monthly values $\left(\mathrm{MAT}_{i, 1961-1990)}\right.$ ) and monthly standard deviations $\left(\sigma_{1961-1990)}\right)$ were calculated from these daily air temperatures. $\mathrm{ST}_{\mathrm{m}}$ was used to construct a time series of monthly air temperatures at the station $i\left(\mathrm{MAT}_{i}\right)$ from the early $1860 \mathrm{~s}$ until today at the station $i$ by (Hanssen-Bauer, 2005):

$\mathrm{MAT}_{i}=\mathrm{MAT}_{1961-1990}+\mathrm{ST}_{\mathrm{m}} \times \sigma_{1961-1990}$

The observed temperature lapse rates during 2008-2010 of 0.5, 0.6 and $0.8^{\circ} \mathrm{C} 100 \mathrm{~m}^{-1}$ at Juvvasshøe, Jetta and Tron, respectively (Farbrot et al., 2011), were used to transfer the so-constructed $\mathrm{MAT}_{i}$ time series locally to the other borehole locations. The historic air temperature series used as input data for the modelling, therefore, consists of monthly values until 2008 and measured daily values for 2008-2011.

Concerning the future air temperature series for the climate change model runs, the rather moderate A1B emission scenario was chosen. The A1B scenario assumes balanced use of all energy sources with an increase in renewable 
energy sources, therefore, assuming a decrease of $\mathrm{CO}_{2}$ emissions by mid 21st century (IPCC, 2007). The likely range of the global mean temperature change from 1990 to 2100 of the A1B scenario is between $+1.7{ }^{\circ} \mathrm{C}$ and $+4.4{ }^{\circ} \mathrm{C}$, with a best estimate of $+2.8^{\circ} \mathrm{C}$ (IPCC, 2007). Temperatures from an ensemble of $>30$ different GCMs were empirically-statistically downscaled to the weather station Fokstugu (Benestad, 2005, 2011), which is located between the Jetta and Tron sites, and used to drive the ground heat flow model. The measured daily air temperatures of S1 and S2 at each borehole were correlated to Fokstugu yielding $r^{2}$-values of $>0.9$. This allowed the construction of air temperature scenarios for each individual borehole from 2010 until 2100 by correcting for a constant bias, specific for each site.

The following air temperature data series are, therefore, available as input data for the historic and future permafrost modelling studies: a time series of monthly means from 1860 to 2008 , measured daily means from 2008 until 2011 and monthly means from 2012 until 2100.

\subsection{Model initialization and boundary conditions}

The finite-difference scheme for solving Eq. (1) requires boundary conditions at the upper and lower ends of the domain. Here, we used a geothermal heat flow of $Q_{\text {geo }}=33 \mathrm{~mW} \mathrm{~m}^{-2}$ (Isaksen et al., 2001) as lower boundary condition and GST as upper boundary condition.

The atmosphere-ground coupling is an important factor for prescribing appropriate upper boundary conditions for the heat flow model. The relation between $T_{\mathrm{AIR}}$ and GST varies strongly from borehole to borehole, depending on snow and surface cover (Fig. 4). Historical and future time series of GST were generated from the reconstructed $T_{\mathrm{AIR}}$ and downscaled future temperatures, respectively, using $n$ factors. $n$-factors are considered as transfer functions relating $T_{\text {AIR }}$ to GST during freezing $\left(n_{\mathrm{F}}\right)$ and thawing $\left(n_{\mathrm{T}}\right)$ conditions (Smith and Riseborough, 2002; Lunardini, 1978). The $n$-factors were derived from measured daily GST and $T_{\mathrm{AIR}}$ at each borehole by calculating the ratios of annual sums of freezing (FDD) and thawing degree days (TDD) of GST to those of $T_{\mathrm{AIR}}$ :

$n_{F}=\frac{\mathrm{FDD}_{\mathrm{S}}}{\mathrm{FDD}_{\mathrm{A}}}$

$n_{T}=\frac{\mathrm{TDD}_{\mathrm{S}}}{\mathrm{TDD}_{\mathrm{A}}}$

where indices $\mathrm{S}$ and $\mathrm{A}$ refer to the temperature at the ground surface and the air, respectively (Riseborough, 2007). FDD and TDD were calculated for the whole year and not based on freezing and thawing seasons at the ground surface, using average daily air temperatures. Sites having a thick snow cover are characterised by a GST $>T_{\mathrm{AIR}}$ during large parts of the winter and, therefore, $n_{\mathrm{F}}<1 . n_{\mathrm{T}}>1$ indicates a higher GST than $T_{\mathrm{AIR}}$ during summer, which can be the case at bedrock sites in the absence of vegetation or on south-facing slopes.

The reconstruction of historic permafrost conditions employs monthly air temperatures, whereas $n$-factors were determined from diurnal data. We investigated the possible effect of this inconsistency in temporal resolution on the $n$ factor values by recalculating $n$-factors based on monthly data. We found that the values deviate by less than $9 \%$ and, therefore, we use the same $n$-factors throughout our study, regardless of whether they are applied to monthly or daily temperatures. For the long-term modelling, mean values of $n_{\mathrm{F}}$ and $n_{\mathrm{T}}$ of S1 and S2 were used (Table 1), assuming representativeness of our observation period. $n_{\mathrm{F}}$-values range from 0.2 and 0.4 at boreholes with a thick snow cover (TroBH1, Tro-BH2, Jet-BH1, Jet-BH2 and Juv-BH6) and from 0.8 to 1.0 where snow cover was moderate (Table 1$). n_{\mathrm{T}^{-}}$ values $>1.2$ were obtained for bedrock boreholes without vegetation cover.

The model was initialised in two different ways, one for the calibration and validation procedure and the other one for the historical permafrost modelling. Simulations of S1 and S2 were initialised from observed profiles of GT which were extrapolated to the full depth assuming a linear gradient. Long-term simulations were started from steady-state corresponding to the mean air temperature of the decade 1860-1869. To account for seasonal variations a second degree Fourier curve function,

$T=a_{0}+\sum_{i=1}^{2} a_{i} \cos (i w t)+b_{i} \sin (i w t)$

is fitted to the observed daily $T_{\mathrm{AIR}}$ of S1 (fit parameters $a_{i}$, $\left.b_{i}, \omega\right)$. The higher degree function was chosen to appropriately represent the asymmetric seasonal cycle introduced by the long and cold winter season. Using $\left(a_{1}, a_{2}, b_{1}, b_{2}, \omega\right)$

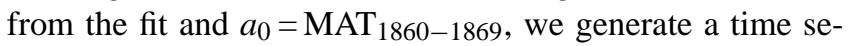
ries of air temperatures, which the model is forced with until no more changes in GTs occur.

\subsection{Model calibration}

In absence of detailed data on the thermal properties of the subsurface (in terms of $c, k, \rho$ and VWC), we empirically determined the values by adjusting until satisfying agreement between model results and available observations over the calibration period. We selected $\mathrm{S} 1$ as calibration period, while S2 and S3 were kept as independent control for subsequent model validation (see following section). For calibration, the model was forced by the measured ground surface temperature as upper boundary condition. A manual, stepwise optimization procedure was applied to avoid erroneous parameter calibration which may result from compensating effects. Our approach to deal with this problem was to pre-select narrow ranges of plausible values for the parameters from literature (Williams and Smith, 1989). Within 

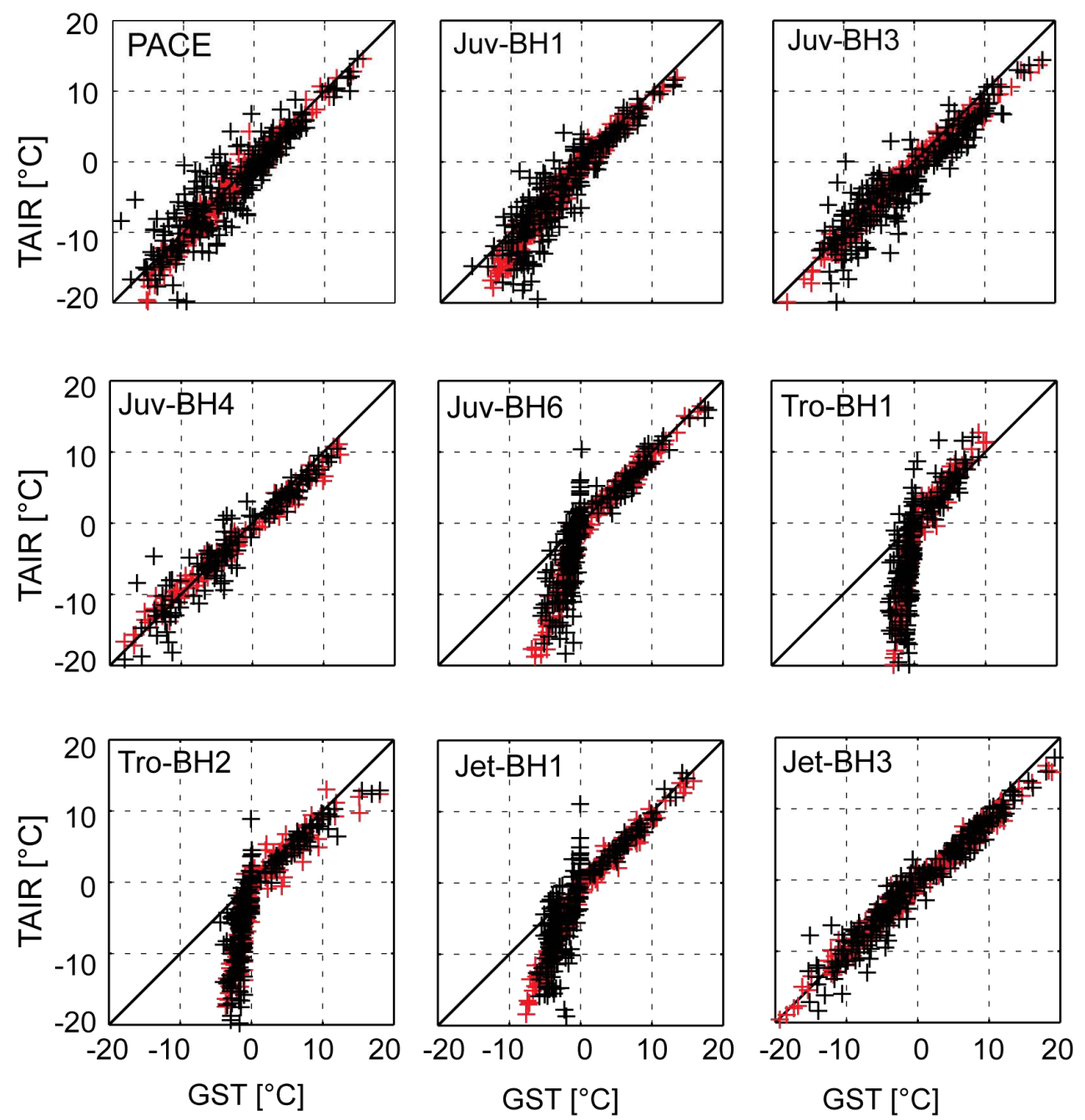

Fig. 4. Relationships between GST vs. $T_{\mathrm{AIR}}$ during the observation period 2008-2010 at the modelled boreholes. Black crosses: measured; red crosses: modelled. The snow-rich sites are clearly visible at the sharp kink at $T_{\mathrm{AIR}} \sim 0{ }^{\circ} \mathrm{C}$. The best correlations are found at sites with thin or no snow cover, (PACE, Juv-BH1, Juv-BH3 to BH6). At sites with a long-lasting, thick snow cover (e.g., Tro-BH1, Jet-BH1), the $n$-factor-based GST model can still reproduce the GST pattern.

these ranges, we accepted only small changes that did not require large changes in related parameters to achieve improved performance. As such, for example, a wrong choice for heat capacity may cause an exaggerated phase shift of GT with respect to GST which, in turn, may partly be compensated for by enhanced heat conduction. Previous sensitivity testing revealed that within the given bounds, modelled GT were most sensitive to changes in heat conductivity and water content, while heat capacity and density are robustly constrained by literature values. Therefore, after assignment of plausible starting values to the parameters, calibration was performed by systematically changing $k$ and VWC over the given ranges aiming for improving the agreement between modelled and observed GTs at different depth levels. Subsequently, minor adjustments were made to $c_{\text {eff }}$ and $\rho$ to finetune the model performance. The agreement between model and observation was quantified at each individual depth in terms of the Nash-Sutcliffe model efficiency coefficient (ME) (Nash and Sutcliffe, 1970). For bedrock, values for thermal conductivity and density were measured at Juv-BH4 and at all sites at Jetta by the Norwegian Geological Survey (NGU) and these observations served as initial guesses for the calibration. A time series of measured soil moisture (O. Humlum, personal communication, 2011) in the vicinity of some sites (Juv-BH1, Tro-BH1) served as an estimate for the water content in the near-surface sediments. Adopted values for the different materials are shown in Table 2, while depthaveraged values of the ME for each borehole are presented in Table 3.

In total, only slight changes to the starting values had to be applied to achieve satisfactory agreement between modelled and observed GT. We defined satisfaction as ME $>0.7$ 

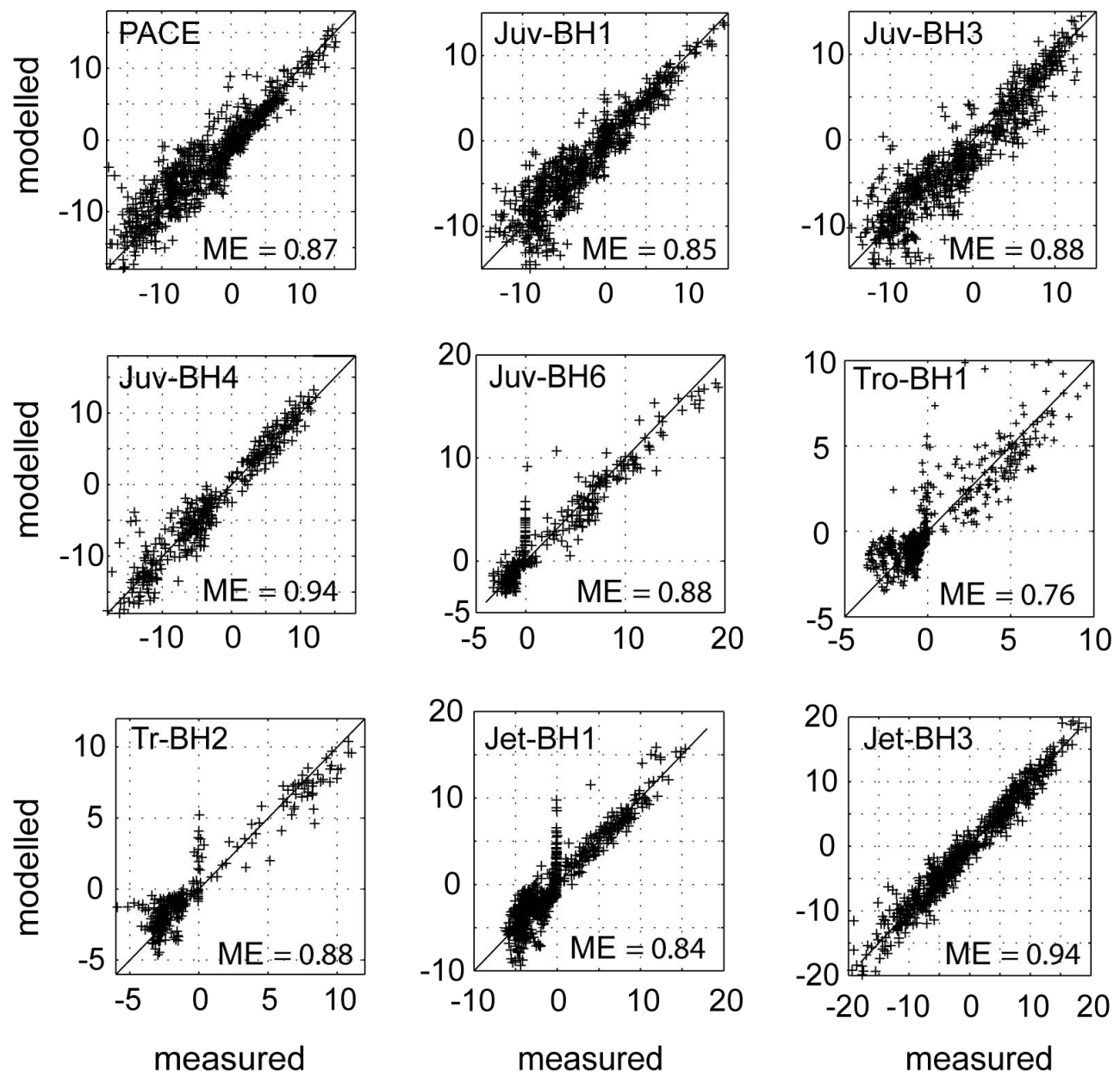

Fig. 5. Modelled vs. measured GST for the period 2008-2011 at modelled boreholes. In general, agreement between modelled and observed values is good with a Nash-Sutcliffe model efficiency coefficient ME $>0.80$ (except for Tro-BH1). At bedrock sites and where the influence of snow cover was limited, an even better agreement was achieved (Juv-BH4, Jet-BH3) with ME > 0.90.

and/or when further changes of parameter values did not yield better model performance. Nevertheless, we emphasize that the obtained set of parameter values for each site represent one possible set that yields satisfactory agreement between model and observations. However, as symptomatic for calibrating numerical models, different sets may exist (Beven and Freer, 2001) and calibrated values may be erroneous. Therefore, transferability of parameter values to other regions is restricted and site-specific calibration is necessary.

\subsection{Model validation}

For our validation procedure we followed Rykiel's (1996) suggestion that the meaning of validation is that a "model is acceptable for its intended use because it meets specified performance requirements" in terms of operational validation. For our study the correspondence between measured and observed GT is expressed by the depth-averaged values of the
Nash-Sutcliffe model efficiency coefficient (ME). Again, we require $\mathrm{ME}>0.7$.

To validate the reliability of the GST model, it was run for each season individually using the average $n$-factors from S1 and S2 (Table 1). For most boreholes a good correspondence between modelled and measured GSTs was achieved with ME $>0.8$ (Table 3, Fig. 5). Since S3 was not included in the average $n$-factor calculation, it represents an additional independent validation period. Despite some differences in the snow conditions, the model reproduced GSTs of S3 equally well (Table 3). The highest values of ME $>0.9$ were achieved at bedrock sites with negligible winter snow cover (Juv-BH4, Jet-BH3). The measured GTs of the validation period (S2-S3) were well reproduced by the calibrated model yielding depth-averaged ME-values ranging from 0.81 to 0.93 (Fig. 6, Table 3). The ME values vary with depth between 0.6 at $10 \mathrm{~m}$ and $>0.9$ close to the ground surface.

To better estimate the model performance on a long-term scale, the model was run from 1860 until 2009 using the 
reconstructed $T_{\mathrm{AIR}}$ series and results compared to the measured GTs of S1. In the case of the PACE borehole modelled and measured GTs of the entire series 1999-2009 were compared down to a depth of $100 \mathrm{~m}$ (Fig. 7). The measured MAGTs were reproduced with a RMSE of $0.6-0.7^{\circ} \mathrm{C}$ (ME $>0.8$ ) in the uppermost part (0 to $1 \mathrm{~m}$ depth) and $0.1-$ $0.3^{\circ} \mathrm{C}(\mathrm{ME}>0.6)$ at a depth between 5 and $10 \mathrm{~m}$ (Fig. 7).

\section{Results}

\subsection{Historical and future air temperature trends}

The historical air temperature series show temperature increases of $1.4^{\circ} \mathrm{C}$ to $2.1^{\circ} \mathrm{C}\left(+0.9^{\circ} \mathrm{C}\left(100 \mathrm{yr}^{-1}\right)\right.$ and $\left.+1.4^{\circ} \mathrm{C}\left(100 \mathrm{yr}^{-1}\right)\right)$ between $1860-1870$ and $2008-2009$ at Juvvasshøe and Tron, respectively. During the last decade (2000-2010), only positive deviations of $T_{\mathrm{AIR}}$ to the climate normal 1961-1990 were observed at all sites (Fig. 8). In the period 1860s until 2000-2009 the strongest warming occurred during spring with $+2.1{ }^{\circ} \mathrm{C}$ at both sites. The more continental site Tron, however, shows strong increases of air temperature both in winter as well as in spring with +1.8 and $+1.9^{\circ} \mathrm{C}$, respectively.

The median of the downscaled future temperatures indicates a further warming of $+2.8^{\circ} \mathrm{C}$ of the decadal means 2001-2010 until 2091-2100. The 10th percentile shows the same warming trend, the 90th percentile, however, shows an increase of $+3.3^{\circ} \mathrm{C}$. The deviation of the median to the climate normal $1961-1990$ amounts to $+3.8^{\circ} \mathrm{C}$ and $+4.2^{\circ} \mathrm{C}$ at Juvvasshøe (Fig. 8b) and Tron (Fig. 8c), respectively.

\subsection{Historic permafrost development}

\subsubsection{Mountain permafrost after the Little Ice Age}

From the initial situation in 1860 , rough estimates on the lower altitudinal limit of mountain permafrost after the LIA can be made. The model results suggest the presence of permafrost at Juvvasshøe at ca. $1300 \mathrm{~m}$ a.s.l. (Juv-BH6). The modelled ALT range from $0.5 \mathrm{~m}$ at $1900 \mathrm{~m}$ a.s.l. (Juv-BH1) to ca. $3 \mathrm{~m}$ at $1300 \mathrm{~m}$ a.s.l (Juv-BH6). The greatest ALT (close to $4 \mathrm{~m}$ ) was modelled for the bedrock site (Juv-BH4). At Tron, permafrost thicknesses of up to $90 \mathrm{~m}$ and ALT of ca. $1.3 \mathrm{~m}$ to $6 \mathrm{~m}$ were modelled. According to the model results, the altitudinal zone of the lower limit of permafrost at this site was below ca. $1300 \mathrm{~m}$ a.s.l.

\subsubsection{Ground temperatures}

According to the model results for the period from 1860 to 2009, GTs were increasing at all depths. At all boreholes, most significant increases in GT occurred in the last two decades (since 1990). The model results show an increase in GT at $10 \mathrm{~m}$ depth since the 1860 s by about $0.9^{\circ} \mathrm{C}$ to $1.5^{\circ} \mathrm{C}$ at Juvvasshøe/Jetta and $0.1^{\circ} \mathrm{C}$ to $0.7^{\circ} \mathrm{C}$ at Tron. GTs at $100 \mathrm{~m}$ depth increased in the range of $0.4^{\circ} \mathrm{C}$ to $1.0^{\circ} \mathrm{C}$ at Juvvasshøe and Jetta and $0.1{ }^{\circ} \mathrm{C}$ to $0.4^{\circ} \mathrm{C}$ at Tron. Modelled warming was strongest for the bedrock borehole (Juv-BH4) with $+1.5^{\circ} \mathrm{C}$ and $+0.5^{\circ} \mathrm{C}$ at $10 \mathrm{~m}$ and $100 \mathrm{~m}$ depth, respectively.

\subsubsection{Active layer thickness}

Depending on location, elevation and stratigraphy, different ALT behaviour is indicated by the model results. A characteristic pattern is observed at all boreholes, with a comparatively slow ALT increase until ca. 1990 and accelerated increase in ALT until 2009.

Trends of ALT increase were, therefore, dderived for the two periods 1860-1864 until 1986-1990 and 1986-1990 until 2009. The non-parametric Mann-Kendall test was used to test these trends for significance (1\% level). At Juvvasshøe and Jetta all trends of ALT increase during both periods have been proven significant, while at Tron only the trend for the later period is significant.

At Juvvasshøe the lowermost borehole (Juv-BH6) shows a very rapid ALT increase and permafrost degradation prior to the end of the 19th century. The increase in ALT until 1990 was only $+0.1 \mathrm{~m}\left(13 \%, \sim 0.1 \mathrm{~cm} \mathrm{yr}^{-1}\right)$ at Juv-BH1 and $+0.2 \mathrm{~m}\left(15 \%, \sim 0.1 \mathrm{~cm} \mathrm{yr}^{-1}\right)$ at PACE (Fig. 9a). The lower boreholes (Juv-BH3 and Juv-BH4) show a stronger increase of ALT with $+0.9 \mathrm{~m}$ resulting in a rate of $\sim 0.6 \mathrm{~cm} \mathrm{yr}^{-1}(27 \%$ at Juv-BH3, $24 \%$ at Juv-BH4). The model results indicate a pronounced ALT increase at all boreholes until 2009 in the range of +0.4 to $+4.1 \mathrm{~m}\left(50-90 \%, 2-22 \mathrm{~cm} \mathrm{yr}^{-1}\right)$. The PACE borehole shows higher mean inter-annual variation of ALT than Juv-BH1 with $+40 \mathrm{~cm} \mathrm{yr}^{-1}$ and $+20 \mathrm{~cm} \mathrm{yr}^{-1}$, respectively. Although Juv-BH3 was drilled in coarse material and Juv-BH4 in bedrock they show a similar ALT evolution, the latter, however, having continuously larger ALT (average $+0.4 \mathrm{~m}$ ) and a much higher mean inter-annual variation of $70 \mathrm{~cm} \mathrm{yr}^{-1}$ compared to $30 \mathrm{~cm} \mathrm{yr}^{-1}$.

As all boreholes are drilled in bedrock at Jetta, the ALT is more sensitive to climate variations and a more rapid increase during the last $150 \mathrm{yr}$ was modelled. Until 1990, the ALT increased by $+1.1 \mathrm{~m}\left(27 \%, \sim 1 \mathrm{~cm} \mathrm{yr}^{-1}\right)$ at Jet-BH1 and $+2.2 \mathrm{~m}\left(40 \%, \sim 2 \mathrm{~cm} \mathrm{yr}^{-1}\right)$ at Jet-BH3, respectively. During the period 1990 until 2009, the strongest increase of ALT of $+2.7 \mathrm{~m}\left(50 \%,+14 \mathrm{~cm} \mathrm{yr}^{-1}\right)$ was modelled at Jet-BH1, while permafrost degraded completely at Jet-BH3 (Fig. 9b).

At Tron the strongest increases in ALT were modelled with $+1.1 \mathrm{~m}\left(110 \%,+0.8 \mathrm{~cm} \mathrm{yr}^{-1}\right)$ until 1990 (Fig. 9c). Since 1990, the model indicates a rapid warming of permafrost with an ALT reaching a depth of $10-11 \mathrm{~m}$ as measured today, resulting in an ALT increase of nearly $+9 \mathrm{~m}$ $\left(430 \%,+87 \mathrm{~cm} \mathrm{yr}^{-1}\right)$. This development agrees well with observations indicating the possible beginning of a talik development (see Fig. 2e) (Farbrot et al., 2011). 

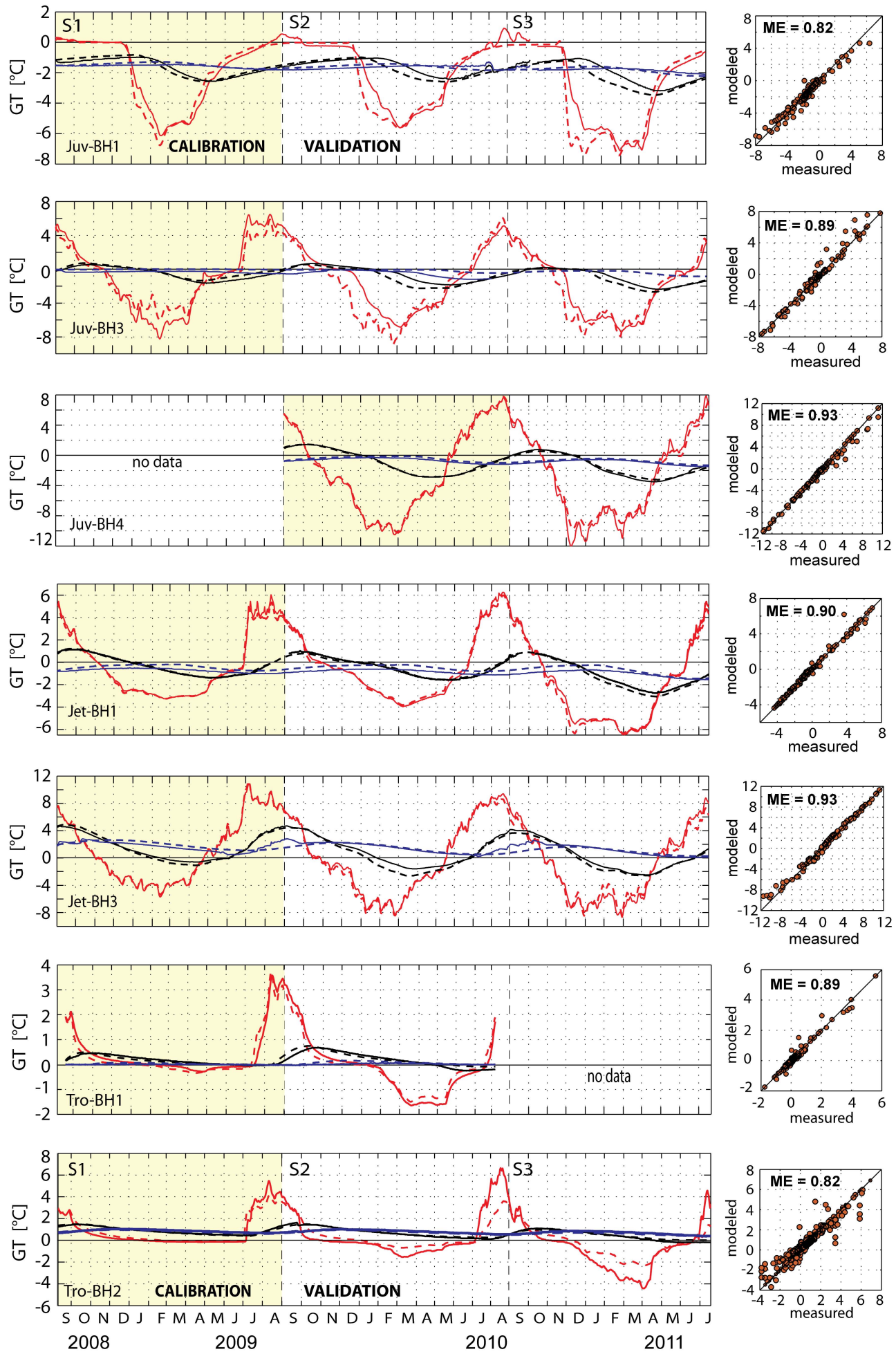

Fig. 6. Left panels: Measured (solid lines) and modelled (dashed lines) ground temperatures (GT) at $1 \mathrm{~m}$ (red), $5 \mathrm{~m}$ (black) and $10 \mathrm{~m}$ (blue) depth during calibration (shaded area) and validation period. At Juv-BH4, data from S1 is not available and S2 served as calibration and S3 as validation period. Right panels: Scatter plots showing measured against modelled GTs of validation period for all depths, including the depth-averaged Nash-Sutcliffe model efficiency coefficients (ME). 
(a)

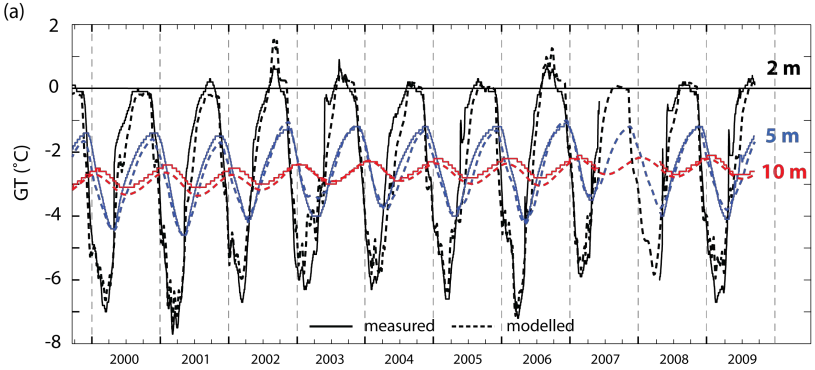

(b)

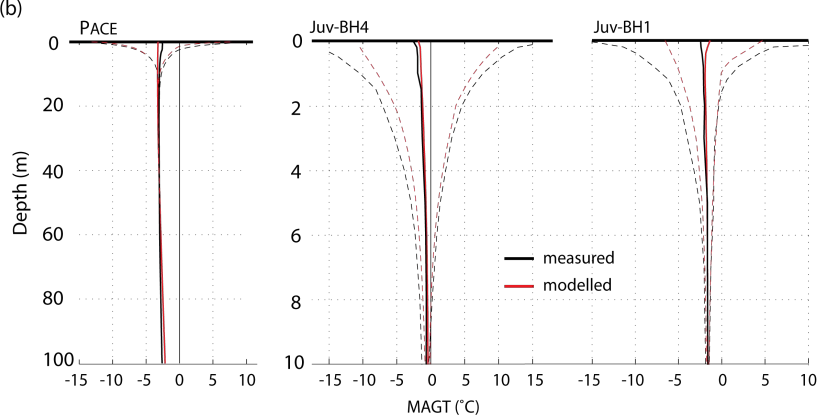

Fig. 7. Comparison of modelled to measured GTs during S1 after 150 model years. The model was run from steady state conditions for 1860 until 2008 using the reconstructed $T_{\text {AIR }}$ series. Both, the seasonal dynamics during 1999-2008 at PACE (a) as well as the MAGTs (b) were reproduced with good accuracy (RMSE $<0.7^{\circ} \mathrm{C}$ ) to a depth of $100 \mathrm{~m}$ (at PACE).
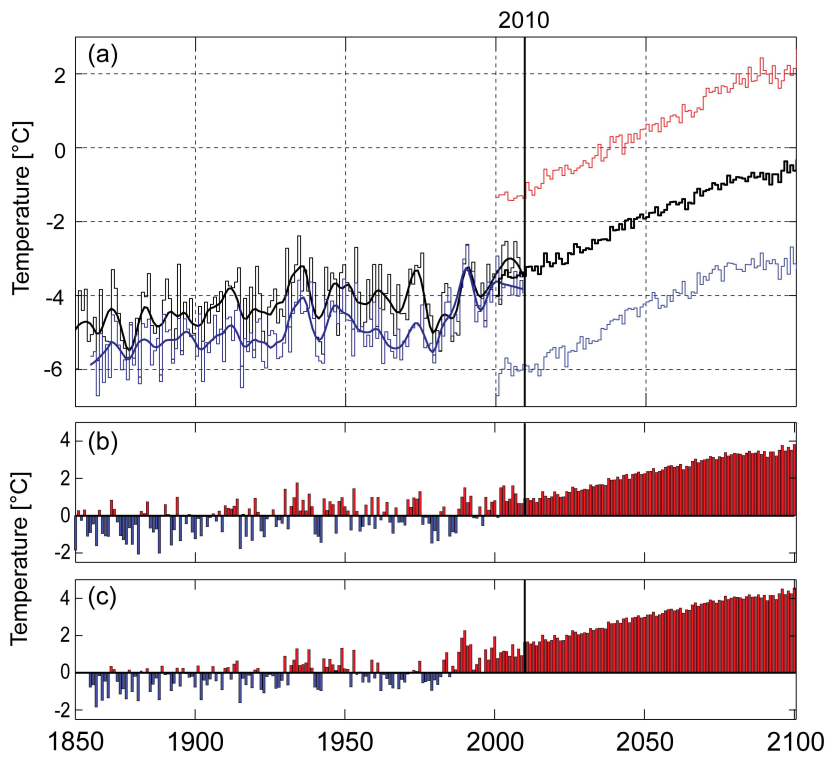

Fig. 8. (a) Historic air temperature series at the uppermost borehole at Juvvasshøe (black) and Tron (blue). The bold line represents the 7-yr Gaussian-filtered series. For 2010 onwards, the figure shows the median (bold black), 90 percentile (red) and 10 percentile (blue) of the downscaled $T_{\text {AIR }}$ ensemble for Juv-BH1. The lower panels show the deviations of MAAT from the 1961-1990 climate normal at Juvvasshøe (b) and Tron (c).

\subsection{Future permafrost development}

\subsubsection{Ground temperatures}

According to modelled GT until 2100, warming will continue beyond that found for 2000-2009. The model suggests that GTs at Juv-BH1 will increase by $+1.9^{\circ} \mathrm{C}$ and $+1.1^{\circ} \mathrm{C}$ at $30 \mathrm{~m}$ and $100 \mathrm{~m}$ depth until 2100 , respectively. Juv-BH4 shows the same warming at $100 \mathrm{~m}$ depth, but a more pronounced increase in GT at $30 \mathrm{~m}$ with $+2.6{ }^{\circ} \mathrm{C}$.

\subsubsection{Active layer thickness}

The model results are indicative for permafrost degradation also above $1800 \mathrm{~m}$ a.s.l. until 2100. Permafrost at lower elevations (Juv-BH3 and Juv-BH4) degrades completely before 2050 (Fig. 9a). At the bedrock site at Jetta the rapid AL thickening rates at Jet-BH1 will continue and the development of a talik until the end of the 2020s is predicted by the model (Fig. 9b).

While the air temperature increase in the climate change scenario shows a linear development and even a decrease in the warming rate (see Fig. 8a), the ALT displays a nonlinear response at most sites (Fig. 9). The ALT of Juv-BH1 increases linearly by another $70 \mathrm{~cm}$ from 2010 until mid-2070s. Although the climate change scenario includes a decrease in the warming rate at this point, a rapid degradation of permafrost subsequently takes place until the end of this century, with a linear increase of ALT by $>40 \mathrm{~cm} \mathrm{yr}^{-1}$. A similar development can be observed at the PACE borehole with higher thickening rates and a permafrost degradation at the mid-2060s.

Running the model with the 90th and 10th percentiles of the downscaled temperature ensemble yields an estimation of the possible range of developments. The 90th percentile causes a fast degradation of permafrost at all boreholes by latest mid of this century (Fig. 9a). Considering the moderate warming projections (10th percentile), permafrost at JuvBH1 and PACE is warming at a slow rate without degradation occurring.

\subsubsection{Probable future of permafrost at the PACE and Juv-BH1 boreholes}

Concerning the projected air temperate, there are uncertainties related to the different formulations of the GCMs themselves, as well as to the empirical-statistical downscaling procedure (Benestad, 2011). Although only one emission scenario is considered here (A1B), the uncertainties lead to considerable spread of projected temperature. In order to quantify the effects of this uncertainty on modelled ALT and GT, the development of GT and ALT until 2100 were simulated for all percentiles of the projected $T_{\mathrm{AIR}}$-ensemble in steps of $5 \%$. From these results, we identify the percentiles which are associated disappearance of the active layer in the years 2050 and 2100 , respectively. This analysis is used to estimate the 

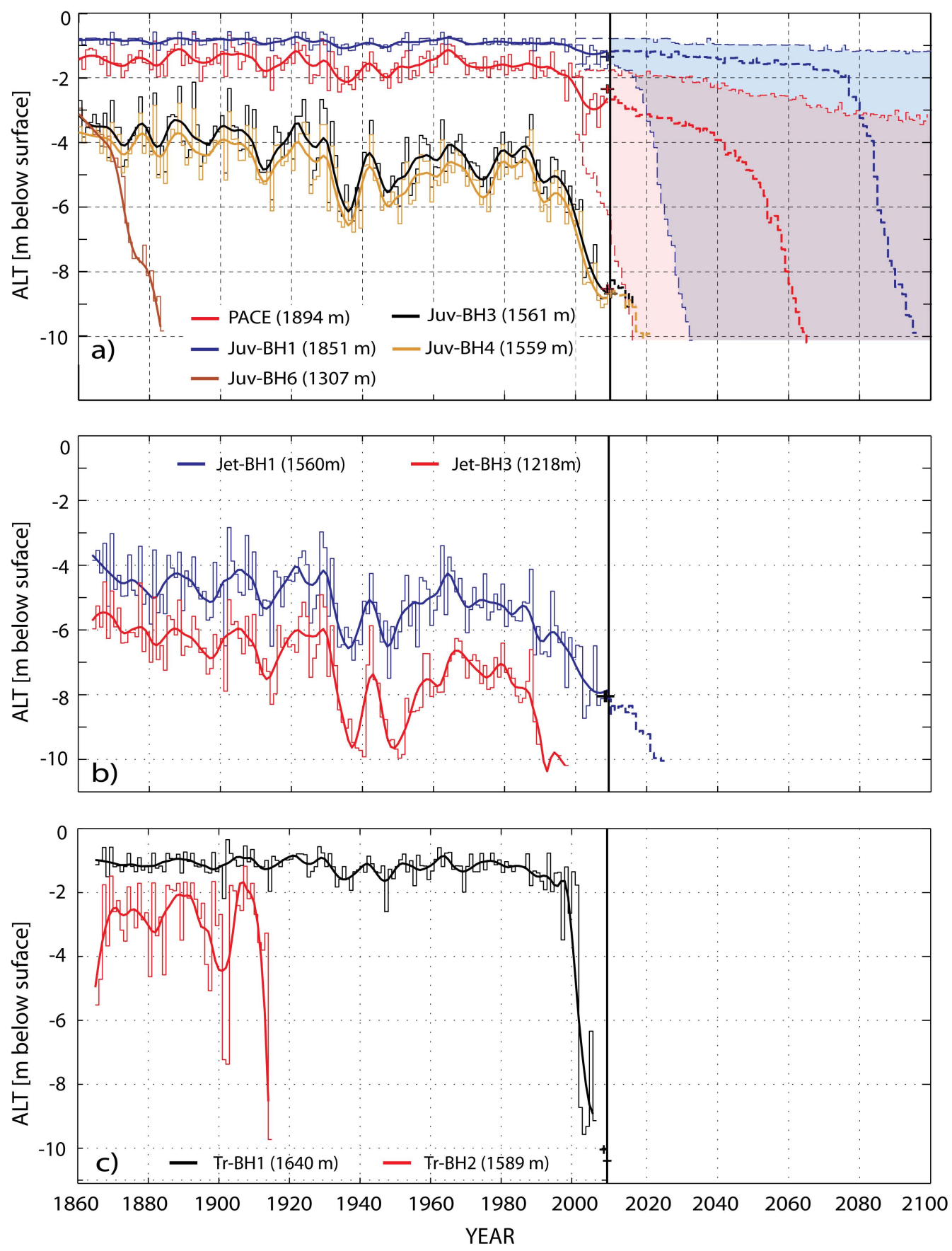

Fig. 9. Reconstructed and projected active layer thickness (ALT) from 1860 to 2100 at Juvvasshøe (a), Jetta (b) and Tron (c). Projected ALT was modelled using the ensemble-median $T_{\mathrm{AIR}}$ (bold dashed lines). ForJuv-BH1 and PACE, also shown are ALT according to the 90 and 10 percentiles (shading) of the $T_{\mathrm{AIR}}$ ensemble. (a). The bold lines represent a 7-yr Gaussian-filtered series, measured ALT are marked by crosses. The model indicates the permafrost degradation at Tron by the year 2010. Therefore, no projection was applied for Tr-BH1.

probabilities for transition of permafrost to talik at Juv-BH1 and PACE in the years 2050 and 2100 (Fig. 10).

For the PACE borehole, a talik evolution until 2100 was modelled already using the 25 th percentile resulting in a high probability of $70-75 \%$ (Fig. 9). According to the classification proposed by the IPCC (IPCC, 2007), this situation is, therefore, likely to occur for the given emission scenario. However, at Juv-BH1 a talik will have developed in 2100 with a probability of $50-55 \%$, and is classified as likely to occur as not. The probabilities for talik evolution until 2050 is $35-40 \%$ for PACE and $20-25 \%$ for Juv-BH1, respectively and, therefore, unlikely (Fig. 10). According to these 


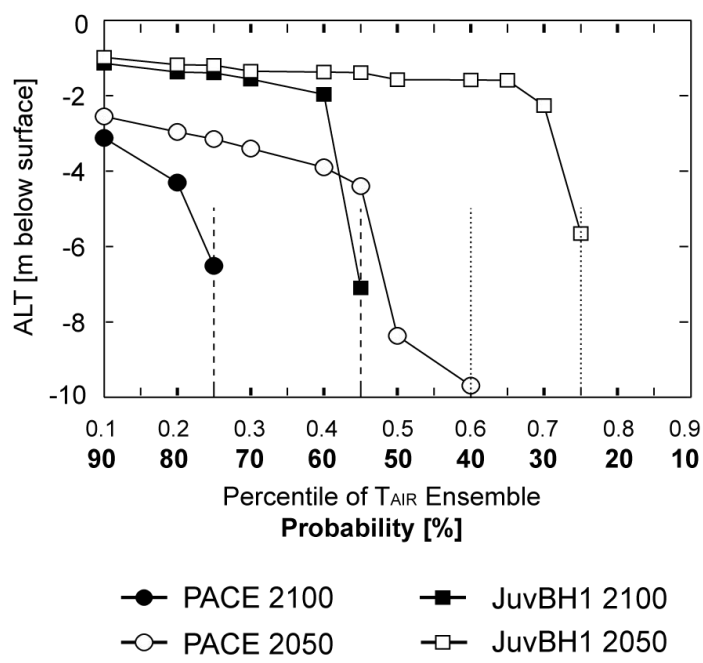

Fig. 10. Probability of permafrost degradation (no refreezing of the active layer) until 2050 (black) and 2100 (white) at Juv-BH1 (squares) and PACE (circles). The assessment is derived from model results for all percentiles of the $T_{\mathrm{AIR}}$ ensemble (in steps of $5 \%$ ) and the probability is defined as the percentile at which seasonal refreezing of the active layer does not occur anymore. Vertical lines mark the probability of this event occurring by 2050 (dashed) and 2100 (dotted), respectively.

model results, above $1800 \mathrm{~m}$ a.s.l, where stable and continuous mountain permafrost is found today, discontinuous mountain permafrost is to be expected by the end of the $21 \mathrm{st}$ century.

\section{Discussion}

\subsection{Model uncertainties due to snow cover, soil water content variability and model approach}

A major source of uncertainty is related to the parameterisation of using constant $n$-factors. It is uncertain how well the snow conditions of the historic and future model period are represented by the average $n$-factor from S1 and S2. A 10 yr record (1999-2008) of GST and $T_{\mathrm{AIR}}$ is available at the PACE borehole (Isaksen et al., 2011), which enables an estimate for the decadal variation of $n$-factors and put the period 2008-2010 into context. A mean $n_{\mathrm{F}}$-factor of $0.91(0.89$ $0.98)$ and $n_{\mathrm{T}}$-factor of $1.12(1.02-1.26)$ was derived from the records. The mean $n_{\mathrm{F}^{-}}$and $n_{\mathrm{T}}$-factors for 2008-2010 (Table 1), therefore, are within the variation of the period 1999-2009. Based on these minimum and maximum values an uncertainty analysis was conducted to give a quantitative estimate on the error that can be expected from $n$-factors. For that purpose, the model was run for the PACE borehole for 1999-2010 separately, both with the minimum and maximum $n$-factors. This implies running the model with the coldest $\left(n_{F}=0.98 ; n_{T}=1.02\right)$ and warmest $\left(n_{F}=0.89\right.$;
$n_{T}=1.26$ ) possible GST conditions. The differences in GTs expressed in the absolute error between the two model runs were calculated for each depth individually. A change in ALT of $<50 \mathrm{~cm}$ and changes in MAGT of $0.7^{\circ} \mathrm{C}$ to $0.4^{\circ} \mathrm{C}$ at the surface and $10 \mathrm{~m}$ depth, respectively, were introduced. The depth-averaged ME varies by less than 0.15 between the extreme value model runs. The PACE borehole represents a site with relatively constant $n_{\mathrm{F}}$-factors due to the negligible snow cover. At sites with higher snow cover and, thus, smaller $n_{\mathrm{F}}$-factors (particularly Tro-BH2, Jet-BH1 and TroBH6), our measurements suggest a higher interannual variability of the $n_{\mathrm{F}}$-factors (Table 1), most likely caused by different wind redistribution of snow. However, the good agreement of modelled long-term subsurface temperatures with measured GT gives us confidence that the $n$-factors assumed in the model runs are a good representation of long-term average $n$-factors.

Some deviations of modelled from observed GTs are observed during periods of thawing and freezing, presumably caused by our assumption of constant VWC. At sites where VWC $>15 \%$, the model underestimates the duration of the zero-curtain effect (see Fig. 5). Further, our model neglects advective heat transport and changes of ice-content in the ground are not recognised in the model. Our modelling does not account for these processes and, therefore, rather represents a minimum estimate for the increase of GT. A third process not included in the model is 3D-effects due to lateral variation of either topography or snow cover.

The aim of this study was to assess the long-term trends of permafrost temperature and its altitudinal distribution. We assume conduction and latent heat effects as main factors, which is in agreement with studies showing that conduction and latent heat effects attribute for most of the heat flow processes (Kane et al., 2001; Weismüller et al., 2011). Both soil water/ice content and snow conditions on the long-term are afflicted with uncertainties. For this study, we suggest that the average $n$-factor value we used provides a useful approximation to address the snow influence on GST. The constancy of soil water content may be responsible for slight deviations during periods of zero-curtain. Nevertheless, observed GT, ALT and GT amplitudes were reproduced reasonably well according to the ME measure used in this study. Longterm data are not available, which e.g., could aid possible trends of $n$-factors or soil water content, so we do not know if and how trends and inter-annual variations would interfere with each other and affect our result. Moreover, at our sites and generally in most high-mountain settings in Scandinavia, coarse-grained near-surface material or bedrock is dominating. Thus, the soil water content is relatively low and the effect of water flow on GT is considered minor. Furthermore, the boreholes have been drilled in flat topography, in doing so, 3D-effects are largely avoided. Processes of lateral heat transfer along a slope and air convection within the pore space of block fields seem not important. 
Even with the stated simplifications, modelled GTs agree well with observations and the present borehole temperature distributions are reproduced when simulating the evolution since 1870. These results suggest, therefore, that our simple approach is capable of capturing the dominating processes within the time scale considered.

\subsection{Uncertainties of reconstructed and projected air temperature series}

The method by Hanssen-Bauer and Nordli (1998) has proven useful in reconstructing reliable air temperature time series (Farbrot and Hanssen-Bauer, 2009). However, it introduces uncertainty due to the spatial and temporal interpolation of air temperatures.

Before daily values become available in 1957, the model is run with monthly data. To test the possible error introduced by the discontinuity in temporal resolution, the period 20082010 was simulated with monthly means. The model result does not show any deviation to those obtained when using the daily resolution input data.

Uncertainties related to the interpolation in mountain topography arise from unknown lapse rates during inversions (Tveito and Førland, 1999), which are observed frequently, especially during calm winter days. The temperature fields used in this study for the long-term record are based on constant lapse rates, which may produce too cold SAT in high elevations (e.g., Tveito and Førland, 1999). However, generally a good fit has been achieved when comparing measured and interpolated air temperature, indicating the mean temperature trends being well represented (Tveito and Førland, 1999).

In our study, we employ ensemble estimates of future $T_{\mathrm{AIR}}$ evolution to illustrate and assess the uncertainty of the future GT evolution. Ensemble analysis has proven powerful in assessing uncertainties of projected $T_{\mathrm{AIR}}$ evolution. However, there are several ways to define an ensemble, each of which refers to a different cause of uncertainty. In detail, the ensemble may consist of GCM realisations for a multitude of emission scenarios, thereby uncovering the range of expected outcomes for the discrete emission scenarios defined by IPCC (2007). Furthermore, a $T_{\mathrm{AIR}}$ ensemble may also consist of many realisations for one single emission scenario, but from a multitude of GCMs. The combination of both would also be possible, though we regard that possibility as little instructive. Here, we have focused on illustrating the uncertainty related to the choice of GCM for a given scenario rather than on the uncertainty related to future emissions. Namely, we have chosen the A1B scenario for which empirically-statistically downscaled time series of $T_{\mathrm{AIR}}$ are available for a multi-model ensemble (Benestad, 2011).

\subsection{Influence of ground properties on thermal regime}

GTs respond differently to warming, depending on the surface material, ground properties and soil water content. The inter-annual change of ALT was calculated and averaged for the period 1860-2009 for all boreholes at Juvvasshøe. Borehole Juv-BH4, which does not have significant snow cover and is located in bedrock, shows the highest variation of $0.7 \mathrm{~m} \mathrm{yr}^{-1}$. Much lower inter-annual ALT variations of $0.2 \mathrm{~m} \mathrm{yr}^{-1}-0.3 \mathrm{~m} \mathrm{yr}^{-1}$ were modelled for boreholes covered by block fields. This reflects how the block fields act as a buffer dampening the effect of the air temperature fluctuations on GT (Harris and Pedersen, 1998; Juliussen and Humlum, 2008). At Juv-BH4, however, no such buffer layer exists causing a more direct response of the ALT to changes in $T_{\mathrm{AIR}}$.

Despite their proximity, the boreholes PACE and Juv-BH1 show different thermal regimes and ALT developments in past and future due to differences in volumetric water content. A large part of the energy transferred into the ground at Juv-BH1 is consumed for melting ground ice. This explains the reduced inter-annual variability of ALT and the less pronounced increase in ALT in the past and future. Furthermore, the nonlinear response in ALT is attributed to the melting of ice within the ground. After melting of ground ice, more energy is available to efficiently warm the ground. Similar effects have been observed in North-America (Smith et al., 2010) and Russia (Romanovsky et al., 2010), where the nonlinear response of GT and ALT to warming are clearly attributable to water content. Similar results have been found comparing the impact of the extreme summer of 2003 on the ALT of bedrock and block field sites in the Swiss Alps (Vonder Mühll et al., 2007).

Several other studies have attempted to quantify the impact of climate change on permafrost conditions, distribution and ALT. Stendel and Christensen (2002) predicted a general increase of ALT of up to 30-40\% until the end of the 21st century in the Northern Hemisphere. Zhang et al. (2008) estimated the ALT increase in Canada to $14-30 \%$ by 2050 compared to a permafrost baseline in the 1990s. For Svalbard, similar changes for the ALT evolution during the 21st century were modelled (Etzelmüller et al., 2011). In our study, the ALT increased by $65 \%$ to $180 \%$ at the boreholes where permafrost still is expected by 2050 . Even the results using the 10th percentile of the climate change models indicate an ALT increase of $44 \%$ at the PACE borehole. This implies a high sensitivity of warm mountain permafrost to climate change, comparable to coastal areas, e.g., on Svalbard (Etzelmüller et al., 2011). Furthermore, many of the assessments mentioned above were made for Arctic lowlands, where large areas with fine-grained and organic-rich sediments are present. Organic components in the near-surface layer are known to effectively damp the GT response to warming (Williams and Smith, 1989). In mountain areas, significant accumulation of organic material is rare and restricted to special topographic 
and geomorphic settings. However, block fields may have an effect similar to that of organic material in Arctic lowlands, i.e., retarding the GT-response to climate signals and cooling the ground, as discussed above.

In summary our modelling study shows a high sensitivity of mountain permafrost and high probabilities of degradation at elevation levels below ca. $1800 \mathrm{~m}$ a.s.l. in Southern Norway. Simulated GTs at bedrock sites are generally more sensitive to climate change than those at sites within block fields or finer-grained sediment cover.

\subsection{Altitudinal changes of mountain permafrost during the modelling period}

This study indicates a major change of the ground thermal regime since the end of the LIA. At that time, sporadic to discontinuous permafrost conditions seem to have been more widespread at elevations of around $1300 \mathrm{~m}$ a.s.l., where we only find permafrost as isolated patches at present (Sollid et al., 2003). This translates to the lower permafrost zone being approximately $200 \mathrm{~m}$ lower during the LIA than at present. At Juvvasshøe, this zone between $1300 \mathrm{~m}$ a.s.l. up to $1500 \mathrm{~m}$ a.s.l. is dominated by block lobes, which may be inactive today, but are shaped by an earlier high-active periglacial environment. Further climate warming would move this zone up-slope. The model results of this study indicate that the lower limit of the discontinuous permafrost zone may rise up to above $1800 \mathrm{~m}$ a.s.l., thus, ca. $250 \mathrm{~m}$ higher than today. With such a scenario, major changes in periglacial processes are expected.

As our results are derived from 1-D modelling at the point scale, these implications on the spatial distribution of mountain permafrost have to be treated with care. The large spatial heterogeneity of parameters that strongly influence permafrost distribution such as snow cover, surface cover and ground parameters were not considered in these estimations, as recently documented by Gubler et al. (2011) for sites in Switzerland and Etzelmüller et al. (2007) in Iceland. Therefore, a simple point-to-area extrapolation is problematic. However, we have three main reasons to consider this setup as sufficient to give estimations on the altitudinal changes of mountain permafrost since the LIA in these very particular mountain areas: (1) The 13 boreholes cover a large altitudinal range from $1900 \mathrm{~m}$ a.s.l. to ca. $1200 \mathrm{~m}$ a.s.l., ranging from continuous permafrost to no permafrost, (2) Farbrot et al. (2011) clearly documented consistent altitudinal trends in GT on an annual average, and (3) even if a borehole location is not representative for the local variability of surface characteristics, the GT signal in greater depth will be integrated over a larger surface area.

\section{Conclusions and perspectives}

A one-dimensional heat flow model was successfully applied to quantify the changes in the thermal regime from 1860 until the end of this century at three mountain sites in southern Norway. The model was calibrated to the individual borehole settings of the study sites and, therefore, is not directly transferable to other regions. However, the settings of the study sites in terms of climate, geomorphology and surface cover are representative for a number of different alpine mountain areas in southern Norway.

The model was forced with reconstructed air temperature series over 1860-2009 and successfully reproduced the vertical ground temperature profiles as measured in 2009 with a good accuracy $(\mathrm{ME} \sim 0.8)$. This confirms the appropriateness of the model to accurately model the permafrost thermal regime over long time scales.

The following conclusions can be drawn from this study:

- From 1860 until ca. 1990 a comparatively small increase in active layer thickness was modelled where permafrost exists, with values ranging from $0.1 \mathrm{~cm} \mathrm{yr}^{-1}$ to $+2 \mathrm{~cm} \mathrm{yr}^{-1}$ (20-68\%). Since ca. 1990 ALT-change rates of $+2 \mathrm{~cm} \mathrm{yr}^{-1}$ to $+87 \mathrm{~cm} \mathrm{yr}^{-1}(20-430 \%)$ were modelled. The model results indicate permafrost degradation at boreholes below ca. $1450-1500 \mathrm{~m}$ at Juvvasshøe and Jetta and below ca. 1600 at Tron.

- Model results suggest that GT at $10 \mathrm{~m}$ depth increased by $+0.9^{\circ} \mathrm{C}$ to $+1.5^{\circ} \mathrm{C}$ over $1860-2009$. The largest part of this warming occurred after 1990.

- Our study successfully simulated the nonlinear response of ground temperature and active layer thickness to increasing air temperatures, due to the thermal inertia of ice-containing ground material. In our sites, this response is related mainly to block fields and coarse ground moraine sites containing ice.

- The modelling study implies that the altitudinal zone covering the lower limit of permafrost at the approximate end of the Little Ice Age was about 200 m lower than today in the field area.

- According to the A1B climate scenario, degradation of mountain permafrost is suggested to occur throughout the 21st century at most of the sites below ca. $1800 \mathrm{~m}$ a.s.l. By the end of this century, the highest locations (Juv-BH1, PACE) will experience pronounced ALT-increases of up to $10 \mathrm{~m}$ or the development of taliks. This implies an upward shift of the lower permafrost zone to around 1800 to $1900 \mathrm{~m}$ a.s.l. by the end of the 21 st century, again depending on sediment characteristics and snow cover development. 
The modelled past and possible future changes in GT and ALT have geomorphologic and geotechnical implications, since the ground thermal regime is a major controlling factor for geomorphologic processes and landscape development (Berthling and Etzelmüller, 2011). As alpine rock faces are widespread in the study area between 1900 and $2400 \mathrm{~m}$ a.s.1, our study suggests major impacts on the geotechnical properties and stability of rock walls. This relationship is welldocumented in literature (Davies et al., 2001; Gruber et al., 2004a) and has to be evaluated in future research. Especially the modelled long period of stable permafrost and a subsequent sudden and quick degradation results in challenges for engineering, natural hazard prediction and mitigation. Finally, our study provides important insights in the range of thermo-physical parameters in a wide range of bedrock and surficial material relevant for mountain areas in Southern Norway. These provide important constraints for spatial numerical permafrost modelling.

Acknowledgements. This study was part of the CRYOLINK project ("Permafrost and seasonal frost in Southern Norway") funded by the Norwegian Research Council (grant number 185987/V30) and the Department of Geosciences, University of Oslo (UiO). Special thanks go to Rune S. Ødegård from the University College in Gjøvik, Norway, for crucial support in field logistics, especially in relation with establishing of the borehole network. Ketil Isaksen (Norwegian Meteorological Institute, Norway) is thanked for valuable logistical support and providing updated temperature records from the PACE boreholes. R. Benestad kindly provided an empirically down-scaled multi-model ensemble of $T_{\mathrm{AIR}}$ for Fokkstua, Southern Norway. Kjersti Gisnås (UiO) contributed during field work. Several land owners at Tron and Juvvasshøe accepted drilling and instrumentation on their properties. The Geological Survey of Norway (NGU) did the measurements of density and thermal characteristics of the samples from the bedrock borehole cores retrieved from the Juvvasshøe (BH5) and the Jetta boreholes. Five anonymous reviewers gave constructive comments, thereby significantly improving the revised manuscript. Likewise, the editor Stephan Gruber is acknowledged for numerous and very useful suggestions to improve the paper. We want to thank all mentioned individuals and institutions.

Edited by: S. Gruber

\section{References}

Benestad, R. E.: Climate change scenarios for northern Europe from multi-model IPCC AR4 climate simulations, Geophys. Res. Lett., 32, L17704, doi:10.1029/2005GL023401, 2005.

Benestad, R. E.: A new global set of downscaled temperature scenarios, J. Climate, 24, 2080-2098, doi:10.1175/2010JCLI3687.1, 2011.

Berthling, I. and Etzelmüller, B.: The concept of cryoconditioning in landscape evolution, Quaternary Res., 75, 378384, doi:10.1016/j.yqres.2010.12.011, 2011.

Beven, K. and Freer, J.: Equifinality, data assimilation, and uncertainty estimation in mechanistic modelling of complex environ- mental systems using the GLUE methodology, J. Hydrol., 249, 11-29, doi:10.1016/S0022-1694(01)00421-8, 2001.

Burn, C. R. and Zhang, Y.: Permafrost and climate change at Herschel Island (Qikiqtaruq), Yukon Territory, Canada, J. Geophys. Res.-Earth, 114, F02001, doi:10.1029/2008JF001087, 2009.

$\mathrm{B} \emptyset$, M. R.: Permafrost studies on Jetta in northern Gudbrandsdalen, central Norway (in Norwegian), Master's thesis, University of Oslo, 127 pp., 1998.

Christiansen, H. H., Etzelmuller, B., Isaksen, K., Juliussen, H., Farbrot, H., Humlum, O., Johansson, M., Ingeman-Nielsen, T., Kristensen, L., Hjort, J., Holmlund, P., Sannel, A. B. K., Sigsgaard, C., Akerman, H. J., Foged, N., Blikra, L. H., Pernosky, M. A., and Odegard, R. S.: The Thermal State of Permafrost in the Nordic Area during the International Polar Year 2007-2009, Permafrost Periglac., 21, 156-181, doi:10.1002/Ppp.687, 2010.

Davies, M. C. R., Hamza, O., and Harris, C.: The effect of rise in mean annual temperature on the stability of rock slopes containing ice-filled discontinuities, Permafrost Periglac., 12, 137-144, doi:10.1002/ppp.378, 2001.

Engelhardt, M., Hauck, C., and Salzmann, N.: Influence of atmospheric forcing parameters on modelled mountain permafrost evolution, Meteorol. Z., 19, 491-500, doi:10.1127/09412948/2010/0476, 2010.

Etzelmüller, B., Farbrot, H., Gudmundsson, A., Humlum, O., Tveito, O. E., and Bjornsson, H.: The regional distribution of mountain permafrost in Iceland, Permafrost Periglac., 18, 185199, doi:10.1002/Ppp.583, 2007.

Etzelmüller, E., Schuler, T. V., Isaksen, K., Christiansen, H. H., Farbrot, H., and Benestad, R.: Modeling the temperature evolution of Svalbard permafrost during the 20th and 21st century, The Cryosphere, 5, 67-79, doi:10.5194/tc-5-67-2011, 2011.

Farbrot, H., Etzelmüller, B., Schuler, T. V., Gudmundsson, A., Eiken, T., Humlum, O., and Bjornsson, H.: Thermal characteristics and impact of climate change on mountain permafrost in Iceland, J. Geophys. Res.-Earth, 112, F03S90, doi:10.1029/2006jf000541, 2007.

Farbrot, H. and Hanssen-Bauer, I.: A simple stationbased empirical model for local snow conditions, Norwegian Meteorological Institute, met.no Report 3/2009,http://met.no/Forskning/Publikasjoner_2009/filestore/ metnoRapport3_2009_mod.pdf,2009.

Farbrot, H., Hipp, T., Etzelmüller, B., Isaksen, K., Ødegård, R. S., Schuler, T. V., and Humlum, O.: Air and ground temperature variations observed along elevation and continentality gradients in Southern Norway, Permafrost Periglac., 22, 343-360, doi:10.1002/ppp.733, 2011.

Fischer, L., Kääb, A., Huggel, C., and Noetzli, J.: Geology, glacier retreat and permafrost degradation as controlling factors of slope instabilities in a high-mountain rock wall: the Monte Rosa east face, Nat. Hazards Earth Syst. Sci., 6, 761-772, doi:10.5194/nhess-6-761-2006, 2006.

Gruber, S. and Hoelzle, M.: The cooling effect of coarse blocks revisited: a modeling study of a purely conductive mechanism, in: Proceedings Ninth International Conference on Permafrost, edited by: Kane, D. L. and Hinkel, K. M., Fairbanks, Institute of Northern Engineering, University of Alaska Fairbanks, 29 June - 3 July, Fairbanks,Alaska, 557-561, 2008.

Gruber, S., Hoelzle, M., and Haeberli, W.: Permafrost thaw and destabilization of Alpine rock walls in the hot summer of 2003, 
Geophys. Res. Lett., 31, L13504, doi:10.1029/2004gl020051, 2004a.

Gruber, S., Hoelzle, M., and Haeberli, W.: Rock-wall temperatures in the Alps: modelling their topographic distribution and regional differences, Permafrost Periglac., 15, 299-307, doi:10.1002/ppp.501, 2004b.

Gubler, S., Fiddes, J., Keller, M., and Gruber, S.: Scaledependent measurement and analysis of ground surface temperature variability in alpine terrain, The Cryosphere, 5, 431-443, doi:10.5194/tc-5-431-2011, 2011.

Gude, M. and Barsch, D.: Assessment of geomorphic hazards in connection with permafrost occurrence in the Zugspitze area (Bavarian Alps, Germany), Geomorphology, 66, 85-93, doi:10.1016/j.geomorph.2004.03.013, 2005.

Haeberli, W.: Construction, environmental problems and natural hazards in periglacial mountain belts, Permafrost Periglac., 3, 111-124, doi:10.1002/ppp.3430030208, 1992.

Hanssen-Bauer, I.: Regional temperature and precipitaion series for Norway: Analyses of time-series updated to 2004, Norwegian Meteorological Institute, 2005.

Hanssen-Bauer, I. and Nordli, P. Ø.: Annual and seasonal temperature variations in Norway 1876-1997m, DNMI Report, Norwegian Meteorological Institute, 1998.

Harris, C., Haeberli, W., Vonder Mühll, D., and King, L.: Permafrost monitoring in the high mountains of Europe: the PACE Project in its global context, Permafrost Periglac., 12, 3-11, doi:10.1002/ppp.377, 2001

Harris, C., Arenson, L. U., Christiansen, H. H., Etzelmüller, B., Frauenfelder, R., Gruber, S., Haeberli, W., Hauck, C., Hölzle, M., Humlum, O., Isaksen, K., Kääb, A., Kern-Lütschg, M. A., Lehning, M., Matsuoka, N., Murton, J. B., Nötzli, J., Phillips, M., Ross, N., Seppälä, M., Springman, S. M., and Vonder Mühll, D.: Permafrost and climate in Europe: Monitoring and modelling thermal, geomorphological and geotechnical responses, EarthSci. Rev., 92, 117-171, doi:10.1016/j.earscirev.2008.12.002, 2009.

Harris, S. A. and Pedersen, D. E.: Thermal regimes beneath coarse blocky materials, Permafrost Periglac., 9, 107120, doi:10.1002/(sici)1099-1530(199804/06)9:2<107::aidppp277>3.0.co;2-g, 1998.

Hoelzle, M., Mittaz, C., Etzelmüller, B., and Haeberli, W.: Surface Energy Fluxes and Distribution Models of Permafrost in European Mountain Areas: an Overview of Current Developments, Permafrost Periglac., 12, 53-68, doi:10.1002/ppp.385, 2001.

Huggel, C., Salzmann, N., Allen, S., Caplan-Auerbach, J., Fischer, L., Haeberli, W., Larsen, C., Schneider, D., and Wessels, R.: Recent and future warm extreme events and highmountain slope stability, Philos T. Roy. Soc. A, 368, 2435-2459, doi:10.1098/rsta.2010.0078, 2010.

IPCC: Summary for Policymakers, in: Climate Change 2007: The Physical Science Basis, in: Contribution of Working Group I to the Fourth Assessment Report of the Intergovernmental Panel on Climate Change, edited by: Solomon, S., Qin, D., Manning, M., Chen, Z., Marquis, M., Averyt, K. B., Tignor, M., and Miller, H. L., Cambridge University Press, Cambridge, UK and New York, NY, USA, 2007.

Isaksen, K., Vonder Muhll, D., Gubler, H., Kohl, T., and Sollid, J. L.: Ground surface-temperature reconstruction based on data from a deep borehole in permafrost at Jansson- haugen, Svalbard, Ann. Glaciol., 31, 2000, 31, 287-294, doi:10.3189/172756400781820291, 2000.

Isaksen, K., Holmlund, P., Sollid, J. L., and Harris, C.: Three deep alpine-permafrost boreholes in Svalbard and Scandinavia, Permafrost Periglac., 12, 13-25, doi:10.1002/ppp-380, 2001.

Isaksen, K., Hauck, C., Gudevang, E., Ødegård, R. S., and Sollid, J. L.: Mountain permafrost distribution on Dovrefjell and Jotunheimen, southern Norway, based on BTS and DC resistivity tomography data, Norsk Geogr. Tidsskr., 56, 122-136, doi:10.1080/002919502760056459, 2002.

Isaksen, K., Heggem, E. S. F., Bakkehoi, S., Odegard, R. S., Eiken, T., Etzelmuller, B., and Sollid, J. L.: Mountain permafrost and energy balance on Juvvasshoe, southern Norway, 8th International Conference on Permafrost, Zurich, Switzerland, ISI:000185049300083, 467-472, 2003.

Isaksen, K., Benestad, R. E., Harris, C., and Sollid, J. L.: Recent extreme near-surface permafrost temperatures on Svalbard in relation to future climate scenarios, Geophys. Res. Lett., 34, L17502, doi:10.1029/2007g1031002, 2007.

Isaksen, K., Ødegård, R. S., Etzelmüller, B., Hilbich, C., Hauck, C., Farbrot, H., Eiken, T., Hygen, H. O., and Hipp, T.: Degrading mountain permafrost in Southern Norway: spatial and temporal variability of mean ground temperatures, 1999-2009, Permafrost Periglac., 22, 361-377, doi:10.1002/ppp.728, 2011.

Juliussen, H. and Humlum, O.: Thermal regime of openwork block fields on the mountains Elgåhogna and Sølen, central-eastern Norway, Permafrost Periglac., 19, 1-18, doi:10.1002/ppp.607, 2008.

Kane, D., Hinkel, K. M., Goering, D., Hinzman, L., and Outcalt, S.: Non-conductive heat transfer associated with frozen soils, Global Planet. Change, 29, 275-292, doi:10.1016/S09218181(01)00095-9, 2001.

Lewkowicz, A. G.: Evaluation of Miniature Temperature-loggers to Monitor Snowpack Evolution at Mountain Permafrost Sites, Northwestern Canada, Permafrost Periglac., 19, 323-331, doi:10.1002/ppp.625, 2008.

Luetschg, M., Lehning, M., and Haeberli, W.: A sensitivity study of factors influencing warm/thin permafrost in the Swiss Alps, J. Glaciol., 54, 696-704, doi:10.3189/002214308786570881, 2008.

Lunardini, V. J.: Theory of N-factors, Third International Conference on Permafrost, Edmonton, Canada, 1, National Research Council of Canada, Ottawa, 40-46, 1978.

Mohr, M.: Comparison of Versions 1.1 and 1.0 of Gridded Temperature and Precipitation Data for Norway, Norwegian Meteorological Institute, met.no Note No. 19/2009, 44 pp., http://met no/filestore/note19-09.pdf, 2009.

Nash, J. E. and Sutcliffe, J. V.: River flow forecasting through conceptual models part I - A discussion of principles, J. Hydrol., 10, 282-290, doi:10.1016/0022-1694(70)90255-6, 1970.

Noetzli, J. and Gruber, S.: Transient thermal effects in Alpine permafrost, The Cryosphere, 3, 85-99, doi:10.5194/tc-3-85-2009, 2009.

Noetzli, J., Gruber, S., Kohl, T., Salzmann, N., and Haeberli, W.: Three-dimensional distribution and evolution of permafrost temperatures in idealized high-mountain topography, J. Geophys. Res.-Earth, 112, F02S13, doi:10.1029/2006JF000545, 2007.

Osterkamp, T. E. and Romanovsky, V. E.: Evidence for warming and thawing of discontinuous permafrost in Alaska, 
Permafrost Periglac., 10, 17-37, doi:10.1002/(sici)10991530(199901/03)10:1<17::aid-ppp303>3.0.co;2-4, 1999.

Ødegård, R. S., Liestøl, O., and Sollid, J. L.: Periglacial forms related to terrain parameters in Jotunheimen, Southern Norway, 5th International Conference on Permafrost, Trondheim, Norway, 59-61, 1988.

Ødegård, R. S., Sollid, J. L., and Liestøl, O.: Ground temperature measurements in mountain permafrost, Jotunheimen, southern Norway, Permafrost Periglac., 3, 231-234, doi:10.1002/ppp.3430030310, 1992.

Ødegård, R. S., Hoelzle, M., Vedel Johansen, K., and Sollid, J. L.: Permafrost mapping and prospecting in Southern Norway, Norsk Geogr. Tidsskr., 50, 41-53, doi:10.1080/00291959608552351, 1996.

Ødegård, R. S., Isaksen, K., Mastervik, M., Billdal, L., Engler, M., and Sollid, J. L.: Comparison of BTS and Landsat TM data from Jotunheimen, southern Norway, Norsk Geogr. Tidsskr., 53, 226233, doi:10.1080/002919599420811, 1999.

Riseborough, D.: The effect of transient conditions on an equilibrium permafrost-climate model, Permafrost Periglac., 18, 21-32, doi:10.1002/ppp.579, 2007.

Romanovsky, V. E., Sazonova, T. S., Balobaev, V. T., Shender, N. I., and Sergueev, D. O.: Past and recent changes in air and permafrost temperatures in eastern Siberia, Global Planet. Change, 56, 399-413, doi:10.1016/j.gloplacha.2006.07.022, 2007.

Romanovsky, V. E., Drozdov, D. S., Oberman, N. G., Malkova, G. V., Kholodov, A. L., Marchenko, S. S., Moskalenko, N. G., Sergeev, D. O., Ukraintseva, N. G., Abramov, A. A., Gilichinsky, D. A., and Vasiliev, A. A.: Thermal state of permafrost in Russia, Permafrost Periglac., 21, 136-155, doi:10.1002/ppp.683, 2010.

Rykiel, E. J.: Testing ecological models: the meaning of validation, Ecol. Model., 90, 229-244, doi:10.1016/0304-3800(95)00152-2, 1996.

Sazonova, T. S., Romanovsky, V. E., Walsh, J. E., and Sergueev, D. O.: Permafrost dynamics in the 20th and 21 st centuries along the East Siberian transect, J. Geophys. Res.-Atmos., 109, D01108, doi:10.1029/2003JD003680, 2004.

Scherler, M., Hauck, C., Hoelzle, M., Stähli, M., and Völksch, I.: Meltwater infiltration into the frozen active layer at an alpine permafrost site, Permafrost Periglac., 21, 325-334, doi:10.1002/ppp.694, 2010.

Smith, M. W. and Riseborough, D. W.: Climate and the limits of permafrost: a zonal analysis, Permafrost Periglac., 13, 1-15, doi:10.1002/ppp.410, 2002.
Smith, S. L., Romanovsky, V. E., Lewkowicz, A. G., Burn, C. R., Allard, M., Clow, G. D., Yoshikawa, K., and Throop, J.: Thermal state of permafrost in North America: a contribution to the international polar year, Permafrost Periglac., 21, 117-135, doi:10.1002/ppp.690, 2010.

Sollid, J. L., Isaksen, K., Eiken, T., and Ødegård, R. S.: The transition zone of mountain permafrost on Dovrefjell, southern Norway, in: Permafrost, Proceedings of the Eighth International Conference on Permafrost, 21-25 July 2003, Zurich, Switzerland, edited by: Phillips, M., Springman, S. M., and Arenson, L. U., A.A. Balkema, Lisse, 1085-1090, 2003.

Stendel, M. and Christensen, J. H.: Impact of global warming on permafrost conditions in a coupled GCM, Geophys. Res. Lett., 29, 1632, doi:10.1029/2001g1014345, 2002.

Stocker-Mittaz, C., Hoelzle, M., and Haeberli, W.: Modelling alpine permafrost distribution based on energy-balance data: a first step, Permafrost Periglac., 13, 271-282, doi:10.1002/ppp.426, 2002.

Tveito, O. E. and Førland, E. J.: Mapping temperatures in Norway applying terrain information, geostatistics and GIS, Norsk Geogr. Tidsskr., 53, 202-212, doi:10.1080/002919599420794, 1999.

Vonder Mühll, D., Noetzli, J., Roer, I., Makowski, K., and Delaloye, R.: Permafrost in Switzerland 2002/2003 and 2003/2004, Glaciological Report (Permafrost), No. 3/4 of the Cryospheric Commission (CC) of the Swiss Academy of Sciences (ScNat) and Department of Geography, University of Zurich, 106 pp., 2007.

Weismüller, J., Wollschläger, U., Boike, J., Pan, X., Yu, Q., and Roth, K.: Modeling the thermal dynamics of the active layer at two contrasting permafrost sites on Svalbard and on the Tibetan Plateau, The Cryosphere, 5, 741-757, doi:10.5194/tc-5741-2011, 2011.

Williams, P. J. and Smith, W.: The Frozen Earth, Cambridge University Press, 306 pp., 1989.

Zhang, Y., Chen, W. J., and Riseborough, D. W.: Temporal and spatial changes of permafrost in Canada since the end of the Little Ice Age, J. Geophys. Res.-Atmos., 111, D22103, doi:10.1029/2006JD007284, 2006.

Zhang, Y., Chen, W. J., and Riseborough, D. W.: Transient projections of permafrost distribution in Canada during the 21 st century under scenarios of climate change, Global Planet. Change, 60, 443-456, doi:10.1016/j.gloplacha.2007.05.003, 2008. 